\title{
All on Board? New Evidence on Board Characteristics from a Large Panel of UK FTSE Indices
}

\author{
Abdelrhman Yusuf $(\mathbb{D}$ and Mohamed Sherif *(C) \\ Edinburgh Business School, Heriot-Watt University, Edinburgh EH14 4AS, UK; abdelrhman.yusuf@hw.ac.uk \\ * Correspondence: m.sherif@hw.ac.uk
}

Received: 28 May 2020; Accepted: 24 June 2020; Published: 1 July 2020

check for updates

\begin{abstract}
This study analyses whether the board characteristics (diversity attributes, competitive capital, time commitment) of companies listed on the Financial Times Stock Exchange FTSE100 exhibit a different performance compared to those associated with conventional benchmark indices (FTSE250, FTSE SMALLCAP (small capitalisation), FTSE Fledgling, and FTSE All-Shar). Using multivariate analysis and unbalanced panel data over the period 2000-2014, we provide novel evidence on how the UK stock market indices react to diversity in board characteristics. Our findings reveal that different aspects of board characteristics are significantly correlated with the performance of FTSE indices. This study further confirms that boards with high levels of diversity maintain better and more effective levels of governance, in particular for companies listed on FTSE100 and FTSE250. Interestingly, we report that the competitive capital and busyness associated with boards of companies listed on FTSE100 have professional, well-educated, and socially connected boards, and show a clear pattern whereby boards become significantly less competitive as firm size decreases.
\end{abstract}

Keywords: corporate governance; board diversity; board characteristics; UK FTSE indices

JEL Classification: G01; G02; G21; G30

\section{Introduction}

In the past two decades, corporate governance has become a central issue in financial regulation [1,2]. Achieving an effective board of directors as an effective and influential driver of firm performance has become one of the most important subjects of interest for academics from a variety of accounting and finance areas. Furthermore, the current crisis of COVID-19 has tested companies in unexpected and extreme ways. Over the years, researchers have investigated avenues to ascertain the relevance of quality of corporate governance and board of directors outputs to the decision procedures and processes for the different end users of that output [3-5].

One such avenue consists of exploring and analysing the concurrent characteristics of boards of directors and quality of corporate governance data on the operations of financial markets; in particular, on the behaviour of stock prices. Overall, this approach attempts to shed light on any possible speculation and inference from agency theory. To date, such research has mainly focused on studying the causal relationship between firm performance and one aspect of board characteristics, especially board statutory diversity [6]. Yet, despite attaining similar findings, studies that have examined the relationship between firm performance and corporate governance (in particular, attributes and diversity of boards of directors) have reached mixed conclusions, and very few studies have investigated how different boards' attributes/diversity have been affected over the years by stakeholder pressures (e.g., media, regulators, and shareholders) [7].

In this paper, we argue that an important and essential interplay exists between different components of board characteristics (i.e., statutory, competitive, and demographic diversity, board 
competitive capital, and board time commitment) at both a regulatory level and in the context of shareholder pressures. This is critically important, as any assessment of board characteristics as being key indicator of corporate governance is a commonly applied starting point for regulators to gain deep insights regarding the impact of corporate governance quality on stock market FTSE index performance.

Following recent and novel directions in the literature, this paper proposes that board characteristics have an impact on the performance of stock market FTSE indices. Hence, our study examines the relationship between management board characteristics and the listing of FTSE stock market indices. Management board characteristics, including board diversity, competitive capital, and 'busyness' are addressed in the UK context by applying corporate governance theories: namely, agency theory and resource dependence theory. We find, and conclude, that it is essential to establish a healthy board of directors to sustain an efficient financial system.

This study contributes to the existing literature and is important in a number of ways. First, the study adds to the limited number of studies that have examined the impact of board diversity on the performance of stock market indices. Our study provides novel evidence on the role of quality of board of directors (statutory, competitive, and demographic diversity, boards' competitive capital, namely educational qualifications, social networking, and governance experiences, and boards' busyness) when listing companies on stock exchange; and in explaining the stock market abnormal performance. Second, boards of directors are often considered as a key engine of corporate governance systems. It is widely believed that poor board diversity and governance hinder financial markets and economic growth [8-10]. A recent stream of research indicates that board governance and effectiveness potentially play a key role in shaping the performance of firms listed on different stock market indices [11,12]. This implies that different requirements in relation to board governance may have significant impacts on companies in difference indices. However, despite growing research on the determinants of stock market indices, there is limited evidence on the effect of board governance and characteristics on companies listing on and across different stock markets. Our study therefore attempts to fill this void and provide insights for the companies' management, government, regulators, and other stakeholders in terms of investment decisions and policy considerations. Furthermore, we explore the earlier board characteristics as the three main antecedents of board task performance. Thus, our study attempts to assess previous findings and also contribute additional evidence by (a) assessing whether there are significant differences in the board diversity attributes across various FTSE indices; (b) examining whether significant differences exist in the boards' competitive capital across various FTSE Indices, and (c) exploring whether the level of boards' busyness across various FTSE indices differs. Third, we consider five Financial Times Stock Exchange (FTSE) indices; namely FTSE100, FTSE250, FTSE SMALLCAP, FTSE Fledgling, and FTSE All-Share. (FTSE100 index comprises the 100 largest firms whose shares are listed on the London Stock Exchange (LSE), whilst the FTSE250 index (15\% of UK market capitalisation) comprises the 250 largest, mid-capitalised, firms listed on the London Stock Exchange (LSE) after the FTSE100. The FTSE350 index is simply a combination of the previous two indices; FTSE100 and FTSE250. The FTSE SMALLCAP index comprises small-capitalised firms that consist of the 351st to the 619th largest-listed firms. The FTSE All-Share combines all three indices, the FTSE100, FTSE250, and SMALLCAP, and represents 98-99\% of UK market capitalisation. Finally, the FTSE Fledgling index comprises 200 listed firms which are considered to be smaller than their counterparts on the FTSE All-Share).

Finally, it is also important to analyse and compare board structures across the different indices due to the inherent different requirements and responsibilities expected from each index. For instance, the UK corporate governance codes require FTSE100 and FTSE250 indices to disclose the 'independence' status for each Non-executive Director (NED), whereas the FTSE SMALLCAP is excluded from this provision. Also, UK full-time executive directors are encouraged not to take on more than one non-executive directorship or chairmanship in a FTSE 100 company. Furthermore, FTSE100 and FTSE250 are prone to a greater level of scrutiny as a result of the interval re-election period, 
which ranges between one and three years. What is more, in addition to all differences in regulatory requirements, not all FTSE indices are subject to the same pressure from media and stakeholders. Thus, the cumulative effect of these differences highlights how imperative it is to distinguish between different UK indices when analysing and comparing corporate governance issues.

The remainder of this paper is structured as follows. Section 2 provides a literature review of studies that have considered a board's characteristics and their impact on stock returns. This is done in particular in order to support the formulation of our research questions. Section 3 provides details of the data and methodology adopted. Section 4 presents the empirical findings, and Section 5 concludes the paper, stating the significance of the main findings and outlining avenues for future research.

\section{Review of Theory, Literature and Hypothesis Development}

In what follows, we first review the research associated with the theoretical framework used in examining the correlation between corporate governance and firm performance. Then, we explain why we see a need for further studies on board characteristics and governance, particularly in listing corporate settings and context. Finally, we review studies that explore and explain the role of board diversity, board competitive capital, and board busyness in enhancing firm performance and value.

\subsection{Review of Theory}

The distinctive nature of a company's board of directors has long been investigated in both the economic and financial literature. The key dominant perspective in the economics and finance literature of corporate governance is associated with agency theory. This theory assumes that monitoring is perceived as the main role of boards and if executed diligently, will reduce agency cost and indirectly impact on firm performance, thereby implying that effective monitoring is a function of board independence. Consequently, researchers in the area have examined the association between board composition as a construct for board independence and a wide range of other board- and firm- levels outcomes [13-17]. Board composition refers to "the number of board members and the configuration of competence and characteristics among them" [18] (p.S68). However, empirical evidence on the relationship between the different board statutory diversity (BSD)'s recommendations and corporate performance is not conclusive [19-21]. Another key hypothetical perspective has been advocated by sociologists and management scholars [22,23]. It is constructed using the resource-based view [24] and resource dependence theory [25]. Such a perspective argues that directors, through their vocational and personal qualifications and networks, provide valuable 'resources' to the firm. In this line, Pfeffer and Salancik [25] claim that "when an organization appoints an individual to a board, it expects the individual will come to support the organization, will concern themselves with its problems, will variably present it to others, and will try to aid it" [25] (p.163). Moreover, they argue that firm performance is enhanced by reducing the firm's dependency on the external environment and in turn enabling access to important external resources. Thus, board competitive capital or board capital/competence has emerged to provide advice and increase firms' outcomes $[18,22,26]$. It is worth noting that board competitive capital includes the directors' relational or social capacity, in addition to their general, functional, board-specific knowledge and skills. These aspects are distinguished from board characteristics, which include "age, tenure, seniority, gender, race, individual behaviour, esteem, influence, independence, integrity and so on" [18] (S69) (we use board competitive capital in this paper due to it reflecting on the difference between a board's skills, which are key in the employment market, and other board characteristics).

One further key argument that has recently been given much attention is related to the behavioural perspective, which combines psychology and sociology literature in general, and particular focuses on groups dynamics [27]. Here, previous literature has tended to focus on the he board's culture rather than the board's role as a decision-making determinant, which in turn affects the board's performance $[18,28]$. This study is thus motivated to explain the board diversity as a prerequisite for enriching boards' culture and firm performances [6,13,16,29-33]. 


\subsection{Literature on Board Characteristics and Firm Governance}

The issue of how the quality of board diversity strengthens shareholder protection and improves firm performance has been the focus of intense debate. Over the last two decades, regulators and policy-makers have paid significant attention to board structures in an attempt to ensure the dominance of independent directors and protect shareholders' interests over boards' different functions. According to Ben-Amar et al. [6] (p. 85), "'statutory' board diversity (SD) refers to the regulation-mandated or highly recommended governance 'best practices' or guidelines put forward in several countries". According to Fama and Jensen [34], the recommendations of board statutory diversity (BSD) assume that a significant presence of independent NEDs on the boardroom enhances the monitoring process, decreases the management's opportunistic tendency, and ultimately protects shareholder value. However, over the last two decades, such assumptions have been empirically challenged by a strand of research that has examined the relationship between such recommendations and firm performance [26,32,35-38]. For example, Daily et al. [26] and Hillman and Dalziel [22] followed a sociological approach to explain how other classes of board diversity influence a firm's outcomes. In another key study, Milliken and Martins [39] introduced the concept of visible and less visible diversity and found supportive evidence for both of these categories with firm performance. In this line, while the board demographic diversity (BDD) is classified as an observable diversity that includes readily detectable attributes such as ethnic background, age, or gender, board competitive diversity $(B C D)$ is less visible and includes underlying attributes such as education, tenure in the organisation, and functional background [16,39]. In this vein also, another body of studies has highlighted the endogeneity problem, which involves estimations of models associated with the relationship between corporate governance and firm performance, and broadly refers to situations in which an explanatory variable is correlated with the error term (see [40,41] for a survey of research on endogeneity).

Similarly, Ben-Amar et al. [6] found a significant relationship between the BDD and firm performance, in particular for decisions associated with mergers and acquisitions. Similarly, Agrawal and Knoeber [42]; Anderson et al. [29]; and Tuggle et al. [33] have all found a relationship between $\mathrm{BDD} / \mathrm{BCD}$ and firm performance. In contrast, Molz [31], by comparing a managerial dominated board and social/pluralistic board, found only an insignificant relationship between social/pluralistic boards and firm performance. On the regulatory level, the boards' overall diversity, including its different attributes, i.e., $\mathrm{BSD}, \mathrm{BCD}$, and $\mathrm{BDD}$, is generally encouraged under the different UK corporate governance codes and reports [43-45]. For instance, the Davies Report [46] suggested increasing representation of women on the FTSE 100 boards to at least $25 \%$ by 2015 [47].

In line with the echelons theory [48], we argue that a greater heterogeneity among directors' characteristics in the boardroom can lead to a better access to diverse sources of information, more creative discussions, and hence a better capability of dealing with complex issues [33,49]. Overall, the larger the firm is on the FTSE indices scale, the greater the need for a more diversified board. Based on the above arguments, it is hypothesised that:

Hypothesis 1 (H1): Boards with higher scores on diversity maintain greater levels of governance effectiveness of the main UK stock exchange indices.

In the context of board competitive capital, Giannetti et al. [50] found a significant relationship between the proportion of non-independent directors with foreign experience, and the firm's performance. Chen [51] found a significant positive correlation between board capital and R\&D investment and also that CEO power can lessen the positive impact of any measures. In another study, Dalziel et al. [52] argued that directors' human and relational capital (i.e., education, entrepreneurial finance experience, technical experience, and interlocks) have a significant impact on R\&D spending. Tian et al. [53] claimed that different 'combinations' of new CEO background and the hiring board's social capital have a significant impact on market reactions. In the same line, Gore et al. [54] argued that financial experts provide stronger oversight and direction with regard to a firm's financial policies 
and strategies. Haynes and Hillman [55] demonstrated that heterogeneous boards, in terms of both human and social capital, have a significant impact on strategic change and firm performance. Rhee and Lee [56] found that growth of foreign ownership is positively related to the proportion of NEDs with foreign degrees. McDonald et al. [57] found a relationship between acquisition performance and experience of outside (non-executive) directors.

To conclude, as evidenced by Tian et al. [53], very few studies have examined board human and social capital simultaneously, and there is a lack of a systematic, task-relevant classification scheme of board capital. In addition, very few studies have considered both the board's competitive capital and the board's diversity together. Subsequently, in this study, we focus on both antecedents-board competitive capabilities and board diversity-together. With regard to the resource-based view [24] and resource dependence theory [25], boards can be seen as a provider of resources (e.g., advice and counsel, links to external environment). Individual professionalism of management board, director qualifications, and education background of board and their growing network enhance the firm's value by providing valuable 'resources', maximising accessibility to external environment, and improving the key functions of the management board, in terms of monitoring and services [22]. Given the significant requirement for these resources and increasing the capability for the firm to secure them, the large companies listed on different FTSE indices are expected to obtain and achieve higher levels of board competitive capital. We therefore propose our second hypothesis:

Hypothesis 2 (H2): Boards with higher scores on competitive capital maintain greater levels of governance effectiveness of the main UK stock exchange indices.

Undoubtedly, the issue of multiple directorships has been a controversial among researchers, shareholders activists, and policy-makers since the publication of Berle and Means's seminal work in 1932 [13,23,24,58-65]. For example, Fich and Shivdasani [59] demonstrated that firms with an interlocked directorate have significantly lower financial performance. Similarly, Devos et al. [66] found a negative reaction by shareholders to the announcement of directors' appointment who created the interlock. In another key study, Falato et al. [67] examined the effect of multiple directorships on firm performance and found that boards associated with the experience of "attention shocks" i.e., the death of one of its own members, have a negative impact on market and firm performance. On the other hand, other researchers believe that the 'acceptable' number of external board seats should be left to the individuals themselves and the boards to determine [23]. Subsequently, directors are considered as good stewards [68] and can be trusted to find the right balance of responsibilities. Moreover, a director who has multiple directorships plays an important role if external board seats are perceived as enhancing 'social capital' [69]. Harris and Shimizu [70] found that the presence of directors with multiple directorships enhance their firm's acquisitions performance, as these directors are important sources of knowledge and represent an important complement to other types of directors. For the UK, O'Sullivan [71] found that executives are not a significant source of non-executive directors in UK companies.

Subsequently, our study focuses on board busyness rather than individual director busyness, which is in line with the Walker Review's [45] recommendation regarding board busyness in the UK financial sector. The report states that: "The overall time commitment of NEDs as a group on a FTSE 100-listed bank or life assurance company board should be greater than has been normal in the past (p.14)". We therefore propose our third hypothesis:

Hypothesis 3 (H3): Boards with higher scores on busyness maintain greater levels of governance effectiveness of main UK stock exchange indices. 


\section{Data, Variable Construction, and Methodology}

This study provides insights on how successful the UK regulators' endeavours were over the years in increasing the overall diversity, competitiveness, and commitment of UK boards, especially where the "comply or explain" approach was adopted. In doing so, we have demonstrated whether there has been an increase in boards' diversity, capital, and commitment among FTSE100 and other conventional benchmark indices (FTSE250, FTSE SMALLCAP, FTSE Fledgling, and FTSE All-Share). Our sample included all directors sitting on the boards of all public UK firms listed on the LSE over the period 2000-2014. Such a period captures the launching of most key and relevant governance reports, namely the first Combined Code on Corporate Governance [43], the Walker Review [45], the UK Stewardship Code [72], and the Davies report [46]. The data adopted in this study included information on executive and non-executive directors that contained current and historic roles for board positions, employment, and education. The data were obtained from the BoardEx database and were carefully reviewed to detect any errors, and missing data were complemented by manually downloading the firms' annual reports. In this way, we finally constructed board diversity indices for each listed firm. Board characteristics comprised board diversity attributes, including statutory diversity (BSD), competitive diversity (BCD), demographic diversity (BDD), board competitive capital (BCC), and board time commitment. An index was developed for each board diversity attribute (i.e., BSD, BCD, and BDD). BSD focused on board independence, committees' independence, and CEO duality. A board/committee was classified as independent if the proportion of independent NEDs was equal to or more than $50 \%$. CEO duality was a dichotomous variable that equalled one if the CEO and Chairman roles were performed by the same director. BSD for each firm was ranked based on a comparison to the entire sample. For BCD, an index composed of directors' education level, financial professional expertise, governance experience, and tenure was constructed. Following Anderson et al. (2011), Herfindahl and Blau's heterogeneity indices were adopted to measure the diversity of directors' educational level and financial professional expertise. Blau's index was identified as:

$$
1-\sum\left(\begin{array}{c}
2 \\
i
\end{array}\right)
$$

where $p_{i}$ is the proportion of group members in each of the (i) categories.

With regards to the coefficient of variation for directors' governance, these two dimensions were captured in relation to board diversity by experience and tenure. The coefficient of variation was then identified by dividing the standard deviation on the mean (SD/1). Each board type was then given a diversity score based on the heterogeneity of the entire sample. Similarly, an index for BDD combined all demographic dimensions of diversity, including gender, nationality (culture familiarity), and age.

In terms of BCC, this was comprised of three key variables; namely: board accumulated governance experience, board accumulated educational qualifications, and board network size. To account for different board sizes, the average governance experience, educational qualifications, and network size per director were calculated by dividing the board accumulated variable according to its size. Finally, the current study focused on firms' board busyness rather than individual director busyness. Subsequently, and in agreement with previous studies, we used four different measures. A detailed description of the board diversity indicators and other variables are reported in Table 1. 
Table 1. Operationalisation of the variables.

\begin{tabular}{|c|c|c|}
\hline \multicolumn{3}{|c|}{ Board Level Variables } \\
\hline Variable & Description & Source \\
\hline $\begin{array}{l}\text { Board Statutory Diversity } \\
\text { Index (BSD) }\end{array}$ & $\begin{array}{l}\text { Board statutory diversity (BSD) is a score index based on adding points for two dimensions that enhance the level of } \\
\text { statutory diversity of the board. } \\
\text { The first one is CEO role duality, which is a dichotomous variable that equals } 0 \text { if CEO is also chairperson ( } 0 \text { mark) and } \\
1 \text { if not }(1 \text { mark). } \\
\text { The second characteristic is the board independence diversity. This is operationalised with Blau's (1977) heterogeneity } \\
\text { index }\left(1-\Sigma \mathrm{p}_{\mathrm{i}}^{2}\right) \text {, where } \mathrm{p}_{\mathrm{i}} \text { is the proportion of group members in each of the (i). } \\
\text { The sample is then split into four terciles to rank firm's board independence diversity level accordingly (first tercile: } 1 \\
\text { mark, second tercile: } 2 \text { marks, third tercile: } 3 \text { marks, fourth tercile: } 4 \text { marks). } \\
\text { The BSD index ranges between } 1 \text { (lowest) to } 5 \text { (highest) (for comparisons purposes, tables show value ranging between } \\
0 \text { to } 4) \text {. } \\
\text { Board size is measured by the number of directors on the board in a given year. }\end{array}$ & $\begin{array}{c}\text { Annual Reports, } \\
\text { BoardEx }\end{array}$ \\
\hline $\begin{array}{l}\text { Board Competitive } \\
\text { Diversity Index (BCD) }\end{array}$ & $\begin{array}{l}\text { Board competitive diversity (BCD) is a score index composed of four dimensions: directors' education level, financial } \\
\text { expertise, governance experience, and tenure. } \\
\text { The diversity of the directors' educational level is operationalised using the Herfindahl index based on the number of } \\
\text { educational qualifications each director has relative to the rest of the board. } \\
\text { The diversity of the directors' financial expertise is operationalised with Blau's (1977) heterogeneity index to capture } \\
\text { the percentage of directors with financial experience based on having a past CFO/FD role. } \\
\text { Directors' governance experience diversity and tenure diversity are operationalised by using the coefficient of variation } \\
\text { (SD/l) for each one. } \\
\text { Similar to the previous index, the sample is then split into four terciles to rank firm's diversity level on each dimension } \\
\text { accordingly. The BCD index ranges between } 4 \text { (lowest) to } 16 \text { (highest) (for comparisons purposes, tables show value } \\
\text { ranging between } 0 \text { to 12). }\end{array}$ & $\begin{array}{c}\text { Annual Reports, } \\
\text { BoardEx }\end{array}$ \\
\hline $\begin{array}{l}\text { Board Demographic } \\
\text { Diversity Index (BDD) }\end{array}$ & $\begin{array}{l}\text { Board demographic diversity (BDD) is a score index composed of three demographic dimensions of diversity (i.e., } \\
\text { directors' gender, nationality, and age). } \\
\text { The heterogeneity of directors' gender and nationality is operationalised with Blau's index (1977). } \\
\text { Directors' age diversity is measured using the coefficient of variation. } \\
\text { Similar to previous indices, the sample is then split into four terciles to rank firm's diversity level on each dimension } \\
\text { accordingly. The BDD index ranges between } 3 \text { (lowest) to } 12 \text { (highest) (for comparisons purposes, tables show value } \\
\text { ranging between } 0 \text { to 9). }\end{array}$ & $\begin{array}{c}\text { Annual Reports, } \\
\text { BoardEx }\end{array}$ \\
\hline $\begin{array}{l}\text { Board Governance } \\
\text { Experience }\end{array}$ & $\begin{array}{l}\text { Total board governance experience is measured by aggregating the total number of boards that each director has } \\
\text { worked for in year }(\mathrm{t}) \text {. The average governance experience per director is calculated by dividing the total board's } \\
\text { governance experience by its size. }\end{array}$ & BoardEx \\
\hline
\end{tabular}


Table 1. Cont.

\begin{tabular}{|c|c|c|}
\hline \multicolumn{3}{|c|}{ Board Level Variables } \\
\hline Variable & Description & Source \\
\hline $\begin{array}{l}\text { Board Educational } \\
\text { Qualifications }\end{array}$ & $\begin{array}{l}\text { Total board educational qualifications is measured as the aggregate number of professional and academic (i.e., } \\
\text { undergraduate level and above) qualifications that each director has achieved. The average educational qualifications } \\
\text { per director is calculated by dividing the total board's educational qualifications by its size. }\end{array}$ & BoardEx \\
\hline Board Network Size & $\begin{array}{l}\text { Total board network size is operationalised with the aggregate number of people that each director connects with. The } \\
\text { average network size per director is calculated by dividing the total board network size by the board size }\end{array}$ & BoardEx \\
\hline Board Busyness 1 & $\begin{array}{l}\text { Dichotomous variable that equals one if the average number of directorships held by all the directors of a given firm is } \\
\text { equal to or more than three directorships. }\end{array}$ & BoardEx \\
\hline Board Busyness 2 & $\begin{array}{l}\text { Dichotomous variable that equals one if the average number of directorships held by only NEDs of a given firm is } \\
\text { equal to or more than three directorships. }\end{array}$ & BoardEx \\
\hline Board Busyness 3 & $\begin{array}{l}\text { Dichotomous variable that equals one if the majority of the directors of a given firm are classified as busy. A director is } \\
\text { considered busy if they hold three or more directorships. }\end{array}$ & BoardEx \\
\hline Board Busyness 4 & $\begin{array}{l}\text { Dichotomous variable that equals one if the majority of the NEDs of a given firm are classified as busy. A director is } \\
\text { considered busy if they hold three or more directorships. }\end{array}$ & BoardEx \\
\hline Board Busyness 5 & $\begin{array}{l}\text { This measure uses the same method used in board busyness } 3 \text {, however it calculates the number of directorships } \\
\text { differently by considering the workload that each post (directorship) may require. Specifically, one chairmanship post } \\
\text { calculated as three directorships and one deputy chairmanship is considered equal to two directorships. }\end{array}$ & BoardEx \\
\hline Firm Size (ln TA) & Natural log of total assets. Numbers are inflation adjusted. & Datastream \\
\hline $\begin{array}{l}\text { Market adjusted stock } \\
\text { return }\end{array}$ & The Banks and Other Financial Institutions BOFI's annual stock return, net of the FTSE All Shares index. & Datastream \\
\hline ROE & The BOFI's annual return on equity. & Datastream \\
\hline $\begin{array}{l}\text { Number of board seats in } \\
\text { quoted firms }\end{array}$ & The total number of board seats held by NEDs in quoted firms on the report date selected. & BoardEx \\
\hline Educational qualifications & NED's total number of professional and academic qualifications in year $(\mathrm{t})$. & BoardEx \\
\hline Social networks & $\begin{array}{l}\text { NED's total number of connections with other directors, whether past or present via their directorships. These links are } \\
\text { captured through detecting a date overlap of directors sitting on boards, whether quoted, private, not for profit, or } \\
\text { other. This is the method used by BoardEx in identifying number of social networks. }\end{array}$ & BoardEx \\
\hline Tenure, Age, and Gender & $\begin{array}{l}\text { Tenure is measured by the number of years spent by the NED in the focal financial firm. Age is NED's age in a } \\
\text { particular year }(\mathrm{t}) \text {. Gender is a dummy variable that equals to } 1 \text { if the NED is a female, } 0 \text { otherwise. }\end{array}$ & BoardEx \\
\hline Independence & $\begin{array}{l}\text { A dummy variable that equals to } 1 \text { if the NED is reported as independent in the firm's annual report in a given year, } 0 \\
\text { otherwise. }\end{array}$ & $\begin{array}{l}\text { BoardEx, Annual } \\
\text { reports }\end{array}$ \\
\hline
\end{tabular}


To test the hypotheses and address differences among UK FTSE indices, a one-way analysis of variance (i.e., one-way ANOVA) was used. One-way ANOVA is common in assessing the likelihood of three or more distinct groups being different or occurring by chance alone. A large F ratio with a probability of less than 0.05 implies that there is a lower likelihood of any difference between groups occurring by chance alone. However, a significant $\mathrm{F}$ value would only indicate a difference in the means but does not indicate where those differences are. Therefore, our research method was complemented by post-hoc multiple comparison methods (e.g., Least Significant Difference (LSD) t-test and Scheffé's test) for multiple comparisons of group means. While LSD makes no adjustment for the number of comparisons, the Scheffé test adjusts the significance levels to compensate accordingly. Scheffé's procedure estimates the $\mathrm{F}$ statistic with $d . f .=J-1, N-J$, where $J$ equals the number of groups (e.g., $i$ and $j$ ). The $L S D_{i-j}$ is then identified as:

$$
L S D_{i-j}=\frac{\hat{\mu}_{i}-\hat{\mu}_{j}}{S_{\hat{\mu}_{i}-\hat{\mu}_{j}}} \text { Scheffe }=\frac{L S D^{2}}{(J-1)}
$$

It is worth noting that the sole focus of this study was to explore whether there is an association between a number of board characteristics and UK FTSE indices. A number of studies have discussed the direction of this association differently. On the one hand, the majority of these studies have examined how board characteristics (such as board diversity and capital) can impact a firm's performance. On the other hand, very few studies have investigated how certain companies tend to have specific forms of boards (e.g., more diverse or competitive boards).

Regardless of the direction of this relationship, researchers have used regressions to examine the causal relationship between board characteristics and firm performance. With the increasing and ongoing utilisation of regression models, growing attention has been devoted to the endogeneity problem [40]. Indeed, reverse causality raises the spectre of endogeneity with respect to the association between board diversity, capital, and busyness on the one hand and performance on the other hand. Furthermore, the correlation between the regressor (whether it is board-related or performance-related) and unobservable firm-specific characteristics is another potential source of endogeneity [73]. There are a number of remedies that have been used in the corporate governance literature, such as Generalized Method of Moments (GMM) [73], fixed effect models [29,74], and lagged dependent variables [75-77]. However, this was beyond the scope of our study, as we were not testing the direction of the relationship, per se. Rather, we have provided a timely review of this association, if any, between a number of board characteristics and UK FTSE indices. For instance, there are a number of explanations for why the boards of FTSE100 firms are more diverse and competitive. One explanation (in line with agency theory, resource-based view (RBV), and resource dependency theory) is that these capable boards lead to better performance over time. Another explanation (in line with legitimacy and stakeholder theories) is that these firms in questions that are under greater stakeholder scrutiny tend to hire more competitive and diverse board members. Supporting one explanation over the other would require a different analysis (i.e., regression models that rigorously control for endogeneity) and much greater amounts of data so as to control for many other variables.

\section{Empirical Findings}

Our empirical analysis began with the descriptive statistics and distribution of all directors on UK boards. Table 2 shows the characteristics of executive and non-executive directors and the extent to which these were in line with corporate governance codes. Table 2 reports that that firms controlled by executives exhibited significant differences in characteristics at the $1 \%$ level of significance over those firms controlled by non-executives. Overall, two conclusions can be drawn. First, while the executive directors (EDs) held a fewer number of seats on other quoted UK firms (Average $=1.13$ ) in compliance with the UK governance code, non-executive directors (NEDs) held on average 1.83 seats, with $93 \%$ of their external seats for non-executive posts. This implies that EDs are not a significant source of NEDs 
in the UK firms. This finding is in line with O'Sullivan [71] who found that only $22 \%$ of non-executives in his sample were serving executives in other companies. Second, while very few executive directors $(4-10 \%)$, held a membership in one of the three board committees, the non-executives held between $53 \%$ and $69 \%$ of memberships. This implies that NEDs are considered as the main source for recruitment on board committees' membership as advised by the governance practice. Moreover, about $68 \%$ of NEDs were deemed as independent by the firms and reserved their seats for less than six years. Finally, holding a chairmanship position was more common among NEDs (21\%) compared to executives $(9 \%)$, implying solid level of independence in UK firm leadership. With regard to individual competencies, NEDs were significantly more qualified and professional than EDs and also more robust, having been subjected to a range of measures and checks (i.e., governance experience, number of educational qualifications, and social networking). This could be explained by a number of factors: (i) NEDs hold a significant number of board seats, which enables them to gain more experience and build a considerable network (e.g., NEDs on average were connected to 521 other director, compared to only 351 for EDs); (ii) NEDs are significantly older (58 years), hence have distinctly more experience than executives (49 years). In addition, NEDs when considered as a whole were more diverse, with $8 \%$ and $19 \%$ of directors being females and of foreign nationality, respectively.

Table 3 presents the corporate governance characteristics and performance of the UK financial and non-financial listed firms. Financial firms were more compliant with corporate governance 'best practices'. Using a Wilcoxon test, our analysis indicated significant differences between financial and non-financial firms in relation to various elements of corporate governance. Interestingly, financial firms had a lower level of role duality (financial firms $=19 \%$; non-financial firms $=27 \%$ ) and remuneration committee independence (Financial firms $=52 \%$, non-financial firms $=67 \%$ ). However, they had a higher board independence of $55 \%$ compared to $34 \%$ for non-financial firms; audit committee independence (financial firms $=79 \%$; non-financial firms $=68 \%$ ) and nomination committee independence (financial firms $=57 \%$, non-financial firms $=42 \%$ ). As evidenced by skewness, certain boards were more compliant with corporate governance codes. 
Table 2. Characteristics of directors (NEDs vs. EDs) sitting on the boards of UK Public Limited Companies (PLCs) between 1999 and 2014 (Director Level).

\begin{tabular}{|c|c|c|c|c|c|c|c|c|c|c|c|c|c|c|}
\hline \multirow{2}{*}{ Variables } & \multicolumn{6}{|c|}{ Non-Executive Directors } & \multicolumn{6}{|c|}{ Executive Directors } & \multicolumn{2}{|c|}{ Mean-Comp. Tests } \\
\hline & Obs. & Mean & Std. Dev. & 5th & 50th & 95th & Obs. & Mean & Std. Dev. & 5th & 50th & 95th & $T$ & Wilcoxon $\$$ \\
\hline Current Number of Quoted Board Seats & 49,544 & 1.83 & 1.33 & 1 & 1 & 4 & 43,342 & 1.13 & 0.48 & 1 & 1 & 2 & ** & ** \\
\hline Audit Committee Membership & 51,124 & 0.69 & 0.46 & 0 & 1 & 1 & 44,872 & 0.04 & 0.2 & 0 & 0 & 0 & ** & ** \\
\hline Remuneration Committee Membership & 51,124 & 0.67 & 0.47 & 0 & 1 & 1 & 44,872 & 0.05 & 0.21 & 0 & 0 & 0 & ** & ** \\
\hline Nomination Committee Membership & 51,124 & 0.53 & 0.5 & 0 & 1 & 1 & 44,872 & 0.1 & 0.3 & 0 & 0 & 1 & ** & ** \\
\hline Tenure in the board (years) & 49,555 & 5.16 & 5.37 & 0.3 & 3.7 & 14.8 & 43,360 & 5.7 & 5.89 & 0.3 & 3.8 & 17.9 & ** & ** \\
\hline Independence (Independent director) & 51,124 & 0.68 & 0.47 & 0 & 1 & 1 & 44,872 & 0 & 0 & 0 & 0 & 0 & $* *$ & ** \\
\hline Chairman or Vice-Chairman & 51,124 & 0.21 & 0.4 & 0 & 0 & 1 & 44,872 & 0.09 & 0.29 & 0 & 0 & 1 & ** & ** \\
\hline Governance experience (seats) & 49,546 & 3 & 3 & 1 & 2 & 9 & 43,345 & 2 & 1 & 1 & 1 & 4 & ** & ** \\
\hline Governance experience (years) $\ddagger$ & 48,713 & 3 & 4 & 0 & 2 & 10 & 42,363 & 1 & 3 & 0 & 0 & 5.6 & ** & ** \\
\hline Educational Qualifications Resources & 49,555 & 2 & 1 & 0 & 2 & 4 & 43,360 & 1 & 1 & 0 & 1 & 3 & ** & ** \\
\hline Social Networking Resources & 51,124 & 521 & 730 & 10 & 226 & 2113 & 44,872 & 351 & 622 & 9 & 84 & 2030 & $* *$ & ** \\
\hline Director's age (years) & 49,232 & 58 & 9 & 42 & 59 & 71 & 42,917 & 50 & 8 & 37 & 49 & 63 & ** & ** \\
\hline Gender (Female director) & 49,555 & 0 & 0 & 0 & 0 & 1 & 43,360 & 0 & 0 & 0 & 0 & 1 & ** & ** \\
\hline Nationality (Non-British director) & 44,811 & 0 & 0 & 0 & 0 & 1 & 37,921 & 0 & 0 & 0 & 0 & 1 & ** & ** \\
\hline
\end{tabular}

$\S$ Although the t-test is one of the most popular techniques, it assumes that the variable in question is normally distributed in the two groups. On the other hand, Wilcoxon-Mann-Whitney (sometimes called rank sum) is non-parametric test that can be used as an alternative to the t-test when distributional assumptions are in question. $\ddagger$ Governance experience (seats) is based

on number of seats in quoted firms. Governance experience (years) is based on number of years in quoted firms. Level of significance for mean differences is **: 0.05

Table 3. Summary statistics and characteristics of the UK PLCs between 2000 and 2014 (Firm Level).

\begin{tabular}{|c|c|c|c|c|c|c|c|c|c|c|c|c|c|}
\hline \multirow[t]{2}{*}{ Variables } & \multicolumn{6}{|c|}{ UK Non-Financial PLCs } & \multicolumn{6}{|c|}{ UK Public Listed BOFIs } & \multirow{2}{*}{ Wilcoxon Tes } \\
\hline & Obs. & Mean & Std. Dev. & 5 th & 50th & 95th & Obs. & Mean & Std. Dev. & 5th & 50th & 95th & \\
\hline \multicolumn{14}{|c|}{ Panel A: the UK public listed firms' Corporate Governance Characteristics between 1999 and 2014} \\
\hline Duality & 14,472 & 0.27 & 0.45 & 0.00 & 0.00 & 1.00 & 3272 & 0.19 & 0.40 & 0.00 & 0.00 & 1.00 & $* *$ \\
\hline Board Independence & 14,472 & 0.34 & 0.24 & 0.00 & 0.38 & 0.67 & 3272 & 0.55 & 0.35 & 0.00 & 0.58 & 1.00 & $* *$ \\
\hline Audit Committee Independence & 13,570 & 0.68 & 0.41 & 0.00 & 1.00 & 1.00 & 3092 & 0.79 & 0.36 & 0.00 & 1.00 & 1.00 & $* *$ \\
\hline $\begin{array}{l}\text { Remuneration Committee } \\
\text { Independence }\end{array}$ & 13,570 & 0.67 & 0.41 & 0.00 & 1.00 & 1.00 & 3092 & 0.52 & 0.46 & 0.00 & 0.67 & 1.00 & $* *$ \\
\hline $\begin{array}{l}\text { Nomination Committee } \\
\text { Independence }\end{array}$ & 13,570 & 0.42 & 0.41 & 0.00 & 0.50 & 1.00 & 3092 & 0.57 & 0.43 & 0.00 & 0.75 & 1.00 & $* *$ \\
\hline \multicolumn{14}{|c|}{ Panel B: the UK public listed firms' Financial Performance and Size between 1999 and 2014} \\
\hline Market Adjusted Stock Return & 12,631 & $-12.0 \%$ & $52.0 \%$ & $-112.0 \%$ & $-4.5 \%$ & $62.0 \%$ & 2998 & $-6.6 \%$ & $39.0 \%$ & $-82.0 \%$ & $0.1 \%$ & $43.0 \%$ & $* *$ \\
\hline Return on Equity (ROE) & 12,178 & $-5.0 \%$ & $45.0 \%$ & $-95.0 \%$ & $5.8 \%$ & $41.0 \%$ & 2862 & $2.2 \%$ & $35.0 \%$ & $-47.0 \%$ & $5.1 \%$ & $39.0 \%$ & $* *$ \\
\hline Total Assets (£million) & 13,554 & $£ 1289$ & $£ 8048$ & $£ 1.7$ & $£ 50$ & $£ 4444$ & $£ 3068$ & $£ 26,699$ & $£ 158,125$ & $£ 1.8$ & $£ 142$ & $£ 65,489$ & $* *$ \\
\hline
\end{tabular}

Level of significance for mean differences is ${ }^{* *}: 0.05$. Note that the average of firm return includes the numbers for all firms regardless of their performance or size. It also includes firm returns during the financial crisis. 


\subsection{Board Diversity}

Table 4 documents the coefficient results from the investigation of the differences of board size and diversity across the FTSE indices. The results in Table 4 show that the size of board increases with firm size; large firms make complex decisions and hence require sizeable boards. We also captured significant variations of board diversity across FTSE indices. With regard to board independence, we found that small firms were less independent. For instance, the average percentages of independent directors on the FTSE 100 for nomination and remuneration committees were $77.7 \%$ and $94.5 \%$, respectively, which is (unsurprisingly) higher than for FTSE Fledgling firms (60\% and $72.7 \%)$. It is worth noting that the FTSE100 index was more compliant with corporate governance codes, suggesting a greater level of monitoring by regulators, media, and shareholders compared to firms associated with other indices.

Overall, the median of independent directors on FTSE boards ranged between $41 \%$ and $43 \%$. The FTSE100 index had a higher average representation of independent directors $(56 \%)$ over the remaining indices. The FTSE SMALLCAP index had the highest percentage of independent NEDs on boards $(62 \%)$. It is worth noting that the average percentage of independent NEDs on boards is influenced by board size, which was significantly higher for FTSE100 (11 directors) compared to FTSE SMALLCAP (6 directors). Hence, the average percentage of independent boards across years was also identified by classifying the board of directors as independent if it exceeded $50 \%$ of the members of the board. For FTSE100 company boards we found that the average percentage of independent board members was $60 \%$, slightly higher than those associated with FTSE SMALLCAP (58\%) companies. In relation to director knowledge, we found that the boards of FTSE100 companies excelled, with about $70 \%(11 \%)$ of directors having two or more educational qualifications. Moreover, the percentage of independence of the board decreased when moving towards remaining indices. For example, while the median of directors who had two or more educational qualifications in FTSE Fledgling boards was 30\% less than others, the median of directors with past financial professional expertise was $0.0 \%$ for both FTSE SMALLCAP and FTSE Fledgling company boards. One possible explanation is that boards in the top indices are involved in complex decisions, which require the continued presence of such a key category of directors. Interestingly, the average number of years on a board was at its lowest for large firms (FTSE 100) when these were compared to small firms (FTSE Fledgling). This complements the combined code recommendations of re-election intervals: one year for FTSE100 companies, and three years for the remaining indices. It also illustrates the restrictions on FTSE100 companies being involved in developing governance policies.

This suggests that independent directors should serve a shorter period and that they have a constant average age of 56 years across the UK different FTSE indices. Table 4 also demonstrates that female and non-British directors were more represented (12\% and $23 \%$, respectively) in the FTSE100 index companies compared to companies in the remaining indices. The minority representation declined from the top indices to the medium and smaller ones. One explanation is that the FTSE100 have greater media exposure, hence directors are more represented for marketing purposes. Another important reason is that large firms in the LSE are mainly leading international companies with multinational boards of directors. 
Table 4. Boards' diversity across the FTSE UK index series over 2000-2014.

\begin{tabular}{|c|c|c|c|c|c|c|c|}
\hline & Variables & $N$ & Mean & Median & Std. Dev. & p5 & $p 95$ \\
\hline \multirow{11}{*}{ FTSE 100} & Firm Board Size & 1089 & 11.0 & 11.0 & 2.7 & 7.0 & 16.0 \\
\hline & Percentage of Independent Executive Directors (INEDs) on Audit Committee & 1088 & $96.4 \%$ & $100.0 \%$ & $10.0 \%$ & $75.0 \%$ & $100.0 \%$ \\
\hline & Percentage of INEDs on Remuneration Committee & 1088 & $94.5 \%$ & $100.0 \%$ & $11.7 \%$ & $66.7 \%$ & $100.0 \%$ \\
\hline & Percentage of INEDs on Nomination Committee & 1088 & $77.7 \%$ & $80.0 \%$ & $19.7 \%$ & $42.9 \%$ & $100.0 \%$ \\
\hline & Percentage of INEDs on firm's board & 1089 & $55.7 \%$ & $55.6 \%$ & $12.6 \%$ & $33.3 \%$ & $75.0 \%$ \\
\hline & Percentage of directors holding two or more educational qualifications & 1072 & $67.6 \%$ & $69.2 \%$ & $18.8 \%$ & $33.3 \%$ & $93.3 \%$ \\
\hline & Percentage of directors with past financial experience & 1089 & $10.9 \%$ & $10.0 \%$ & $9.2 \%$ & $0.0 \%$ & $27.3 \%$ \\
\hline & Average number of years a director spends on the firm board & 1089 & 5.3 & 5.0 & 2.3 & 2.0 & 9.7 \\
\hline & Average age of directors & 1089 & 56.1 & 56.2 & 2.8 & 51.5 & 60.3 \\
\hline & Percentage of female directors & 1089 & $11.7 \%$ & $10.0 \%$ & $10.0 \%$ & $0.0 \%$ & $30.0 \%$ \\
\hline & Percentage of non-British directors & 1089 & $23.2 \%$ & $20.0 \%$ & $21.0 \%$ & $0.0 \%$ & $63.6 \%$ \\
\hline \multirow{11}{*}{ FTSE 250} & Firm Board Size & 2185 & 8.2 & 8.0 & 2.3 & 5.0 & 12.0 \\
\hline & Percentage of INEDs on Audit Committee & 164 & $94.2 \%$ & $100.0 \%$ & $15.8 \%$ & $66.7 \%$ & $100.0 \%$ \\
\hline & Percentage of INEDs on Remuneration Committee & 2164 & $87.5 \%$ & $100.0 \%$ & $27.6 \%$ & $0.0 \%$ & $100.0 \%$ \\
\hline & Percentage of INEDs on Nomination Committee & 2164 & $72.8 \%$ & $75.0 \%$ & $27.2 \%$ & $0.0 \%$ & $100.0 \%$ \\
\hline & Percentage of INEDs on firm's board & 2185 & $54.5 \%$ & $50.0 \%$ & $19.3 \%$ & $27.3 \%$ & $100.0 \%$ \\
\hline & Percentage of directors holding two or more educational qualifications & 2181 & $54.1 \%$ & $55.6 \%$ & $21.9 \%$ & $16.7 \%$ & $87.5 \%$ \\
\hline & Percentage of directors with past financial experience & 2185 & $9.8 \%$ & $10.0 \%$ & $10.2 \%$ & $0.0 \%$ & $28.6 \%$ \\
\hline & Average number of years a director spends on the firm board & 2185 & 6.0 & 5.5 & 3.4 & 1.4 & 11.2 \\
\hline & Average age of directors & 2185 & 55.5 & 55.6 & 3.9 & 48.8 & 61.7 \\
\hline & Percentage of female directors & 2185 & $8.2 \%$ & $0.0 \%$ & $10.2 \%$ & $0.0 \%$ & $28.6 \%$ \\
\hline & Percentage of non-British directors & 2185 & $12.9 \%$ & $0.0 \%$ & $17.7 \%$ & $0.0 \%$ & $50.0 \%$ \\
\hline \multirow{11}{*}{ FTSE SMALL } & Firm Board Size & 2256 & 6.6 & 6.0 & 1.9 & 4.0 & 10.0 \\
\hline & Percentage of INEDs on Audit Committee & 2242 & $92.8 \%$ & $100.0 \%$ & $17.5 \%$ & $60.0 \%$ & $100.0 \%$ \\
\hline & Percentage of INEDs on Remuneration Committee & 2242 & $68.4 \%$ & $100.0 \%$ & $41.5 \%$ & $0.0 \%$ & $100.0 \%$ \\
\hline & Percentage of INEDs on Nomination Committee & 2242 & $74.3 \%$ & $80.0 \%$ & $32.1 \%$ & $0.0 \%$ & $100.0 \%$ \\
\hline & Percentage of INEDs on firm's board & 2256 & $62.1 \%$ & $57.1 \%$ & $25.5 \%$ & $25.0 \%$ & $100.0 \%$ \\
\hline & Percentage of directors holding two or more educational qualifications & 2249 & $46.0 \%$ & $44.4 \%$ & $23.8 \%$ & $0.0 \%$ & $83.3 \%$ \\
\hline & Percentage of directors with past financial experience & 2256 & $8.3 \%$ & $0.0 \%$ & $10.6 \%$ & $0.0 \%$ & $25.0 \%$ \\
\hline & Average number of years a director spends on the firm board & 2256 & 6.5 & 6.0 & 3.3 & 1.9 & 12.2 \\
\hline & Average age of directors & 2256 & 56.5 & 56.2 & 4.2 & 49.9 & 64.0 \\
\hline & Percentage of female directors & 2256 & $8.8 \%$ & $0.0 \%$ & $12.0 \%$ & $0.0 \%$ & $33.3 \%$ \\
\hline & Percentage of non-British directors & 2256 & $9.3 \%$ & $0.0 \%$ & $16.7 \%$ & $0.0 \%$ & $44.4 \%$ \\
\hline
\end{tabular}


Table 4. Cont.

\begin{tabular}{|c|c|c|c|c|c|c|c|}
\hline & Variables & $N$ & Mean & Median & Std. Dev. & p5 & p95 \\
\hline \multirow{11}{*}{$\begin{array}{c}\text { FTSE } \\
\text { FLEDGLING }\end{array}$} & Firm Board Size & 629 & 5.8 & 5.0 & 2.0 & 3.0 & 9.0 \\
\hline & Percentage of INEDs on Audit Committee & 611 & $91.2 \%$ & $100.0 \%$ & $19.2 \%$ & $50.0 \%$ & $100.0 \%$ \\
\hline & Percentage of INEDs on Remuneration Committee & 611 & $72.7 \%$ & $100.0 \%$ & $35.7 \%$ & $0.0 \%$ & $100.0 \%$ \\
\hline & Percentage of INEDs on Nomination Committee & 611 & $60.0 \%$ & $75.0 \%$ & $37.6 \%$ & $0.0 \%$ & $100.0 \%$ \\
\hline & Percentage of INEDs on firm's board & 629 & $52.6 \%$ & $50.0 \%$ & $23.4 \%$ & $12.5 \%$ & $100.0 \%$ \\
\hline & Percentage of directors holding two or more educational qualifications & 627 & $39.2 \%$ & $40.0 \%$ & $25.6 \%$ & $0.0 \%$ & $80.0 \%$ \\
\hline & Percentage of directors with past financial experience & 629 & $6.7 \%$ & $0.0 \%$ & $10.4 \%$ & $0.0 \%$ & $25.0 \%$ \\
\hline & Average number of years a director spends on the firm board & 629 & 7.8 & 7.2 & 4.1 & 2.1 & 16.1 \\
\hline & Average age of directors & 629 & 56.9 & 56.9 & 4.6 & 49.5 & 64.6 \\
\hline & Percentage of female directors & 629 & $5.2 \%$ & $0.0 \%$ & $9.0 \%$ & $0.0 \%$ & $25.0 \%$ \\
\hline & Percentage of non-British directors & 629 & $6.9 \%$ & $0.0 \%$ & $15.0 \%$ & $0.0 \%$ & $40.0 \%$ \\
\hline \multirow{11}{*}{$\begin{array}{c}\text { FTSE AIM } \\
\text { ALL SHARE }\end{array}$} & Firm Board Size & 5834 & 5.4 & 5.0 & 1.7 & 3.0 & 8.0 \\
\hline & Percentage of INEDs on Audit Committee & 5372 & $49.5 \%$ & $50.0 \%$ & $43.7 \%$ & $0.0 \%$ & $100.0 \%$ \\
\hline & Percentage of INEDs on Remuneration Committee & 5372 & $48.8 \%$ & $50.0 \%$ & $43.3 \%$ & $0.0 \%$ & $100.0 \%$ \\
\hline & Percentage of INEDs on Nomination Committee & 5372 & $21.1 \%$ & $0.0 \%$ & $34.7 \%$ & $0.0 \%$ & $100.0 \%$ \\
\hline & Percentage of INEDs on firm's board & 5834 & $23.6 \%$ & $22.2 \%$ & $22.4 \%$ & $0.0 \%$ & $60.0 \%$ \\
\hline & Percentage of directors holding two or more educational qualifications & 5815 & $43.0 \%$ & $40.0 \%$ & $25.4 \%$ & $0.0 \%$ & $83.3 \%$ \\
\hline & Percentage of directors with past financial experience & 5834 & $3.2 \%$ & $0.0 \%$ & $7.4 \%$ & $0.0 \%$ & $20.0 \%$ \\
\hline & Average number of years a director spends on the firm board & 5834 & 4.9 & 4.2 & 3.6 & 0.7 & 12.0 \\
\hline & Average age of directors & 5834 & 53.8 & 54.0 & 5.2 & 44.9 & 62.0 \\
\hline & Percentage of female directors & 5834 & $4.5 \%$ & $0.0 \%$ & $9.3 \%$ & $0.0 \%$ & $25.0 \%$ \\
\hline & Percentage of non-British directors & 5828 & $13.9 \%$ & $0.0 \%$ & $22.7 \%$ & $0.0 \%$ & $66.7 \%$ \\
\hline
\end{tabular}


Shifting the attention to different attributes and forms of board diversity, Table 5 presents the distribution of all three diversity forms (i.e., BSD, BCD, and BDD) by the FTSE Index Series in panels A, B, and C, respectively. Panel A shows that the FTSE100 featured the highest level of BSD (mean 3), followed by FTSE250 firms (mean 2.8), FTSE SMALLCAP firms (mean 2.3), and FTSE Fledgling firms (mean of 2.4). Table 5 also demonstrates that the key difference between BSD scores for the FTSE100 index was statistically significant at a $1 \%$ level of significance. Overall, results shown in panel A suggest that the top firms are more committed to the statutory diversity criteria as promoted by corporate governance codes. Panel B exhibits the level of BCD for all three indices. As before, the FTSE100 had the highest BCD mean with a score of 6.2. However, it was not statistically different from the level of BCD of the FTSE250 or the FTSE SMALLCAP. In contrast, the BCD mean of the FTSE Fledgling index was significantly lower than the BCD associated with the remaining FTSE indices at $1 \%$ level of significance. Panel D combines firms from the FTSE100 and FTSE250 (i.e., FTSE350) indices versus a composition of FTSE SMALLCAP and Fledgling firms. Our analysis showed that the BCD level was significantly lower than those associated with FTSE350 firms. Finally, panel C presents the BDD level of differences across all indices. Similar to the BSD and BCD levels, the FTSE100 featured the highest level of BDD (mean 4.8) compared to the other indices (FTSE250 mean = 3.6; FTSE Fledgling = mean 2.8) The differences in the BDD mean scores across indices were statistically significant at the $1 \%$ level of significance.

Table 5. Descriptive statistics of board diversity indices and comparisons of group means by the FTSE UK index series over 2000-2014.

\begin{tabular}{|c|c|c|c|c|c|c|c|}
\hline \multicolumn{4}{|c|}{ One-Way ANOVA } & \multicolumn{4}{|c|}{$\begin{array}{l}\text { Scheffé Multiple Group Comparisons: Row } \\
\text { Mean-Column Mean ( } p \text {-Value) }\end{array}$} \\
\hline & Mean & Std. Dev & Frequency & FTSE 100 & FTSE 250 & FTSE SMAL & FTSE FLEDG \\
\hline \multicolumn{8}{|c|}{ Panel A: Statutory Diversity } \\
\hline FTSE100 & 3.0 & 0.9 & 1089 & & & & \\
\hline FTSE 250 & 2.8 & 1.1 & 2185 & $\begin{array}{c}-0.183 \\
0.001 * * *\end{array}$ & & & \\
\hline FTSE SMALL & 2.3 & 1.1 & 2256 & $\begin{array}{c}-0.649 \\
0.000 * * *\end{array}$ & $\begin{array}{c}-0.466 \\
0.000^{* * *}\end{array}$ & & \\
\hline $\begin{array}{l}\text { FTSE } \\
\text { FLEDGLING }\end{array}$ & 2.4 & 1.0 & 629 & $\begin{array}{c}-0.546 \\
0.000 * * *\end{array}$ & $\begin{array}{c}-0.364 \\
0.000^{* * *}\end{array}$ & $\begin{array}{l}0.102 \\
0.429\end{array}$ & \\
\hline $\begin{array}{l}\text { FTSE ALL } \\
\text { SHARES }\end{array}$ & 1.8 & 1.2 & 5834 & $\begin{array}{c}-1.194 \\
0.000 * * *\end{array}$ & $\begin{array}{c}-1.012 \\
0.000 * * *\end{array}$ & $\begin{array}{c}-0.546 \\
0.000 * * *\end{array}$ & $\begin{array}{c}-0.648 \\
0.000 * * *\end{array}$ \\
\hline $\begin{array}{l}\text { Source Between } \\
\text { Groups }\end{array}$ & $\begin{array}{c}\mathrm{df} \\
4\end{array}$ & $\begin{array}{c}\mathrm{F} \\
469.060\end{array}$ & $\begin{array}{l}\text { Prob }>\text { F } \\
0.000\end{array}$ & & & & \\
\hline \multicolumn{8}{|c|}{ Panel B: Competitive Diversity } \\
\hline FTSE100 & 6.2 & 1.9 & 1088 & & & & \\
\hline FTSE 250 & 6.2 & 2.1 & 2178 & $\begin{array}{c}-0.068 \\
0.947\end{array}$ & & & \\
\hline FTSE SMALL & 6.1 & 2.2 & 2253 & $\begin{array}{c}-0.128 \\
0.623\end{array}$ & $\begin{array}{c}-0.060 \\
0.93\end{array}$ & & \\
\hline $\begin{array}{l}\text { FTSE } \\
\text { FLEDGLING }\end{array}$ & 5.6 & 2.4 & 629 & $\begin{array}{c}-0.577 \\
0.000 * * *\end{array}$ & $\begin{array}{c}-0.509 \\
0.000 * * *\end{array}$ & $\begin{array}{c}-0.449 \\
0.000 * * *\end{array}$ & \\
\hline $\begin{array}{l}\text { FTSE ALL } \\
\text { SHARES }\end{array}$ & 4.6 & 2.1 & 5800 & $\begin{array}{c}-1.603 \\
0.000^{* * *}\end{array}$ & $\begin{array}{c}-1.535 \\
0.000 * * *\end{array}$ & $\begin{array}{c}-1.475 \\
0.000 * * *\end{array}$ & $\begin{array}{c}-1.026 \\
0.000 * * *\end{array}$ \\
\hline $\begin{array}{l}\text { Source Between } \\
\text { Groups }\end{array}$ & $\begin{array}{c}\mathrm{df} \\
4\end{array}$ & $\begin{array}{c}\text { F } \\
361.890\end{array}$ & $\begin{array}{c}\text { Prob }>\text { F } \\
0.000\end{array}$ & & & & \\
\hline \multicolumn{8}{|c|}{ Panel C: Demographic Diversity } \\
\hline FTSE100 & 4.8 & 1.9 & 1089 & & & & \\
\hline FTSE 250 & 3.0 & 2.0 & 2185 & $\begin{array}{c}-1.135 \\
0.000^{* * *}\end{array}$ & & & \\
\hline
\end{tabular}


Table 5. Cont.

\begin{tabular}{|c|c|c|c|c|c|c|c|}
\hline \multicolumn{4}{|c|}{ One-Way ANOVA } & \multicolumn{4}{|c|}{$\begin{array}{l}\text { Scheffé Multiple Group Comparisons: Row } \\
\text { Mean-Column Mean ( } p \text {-Value) }\end{array}$} \\
\hline & Mean & Std. Dev & Frequency & FTSE 100 & FTSE 250 & FTSE SMAL & FTSE FLEDG \\
\hline FTSE SMALL & 3.2 & 2.3 & 2,25 & $\begin{array}{l}-1.595 \\
0.000 * * *\end{array}$ & $\begin{array}{c}-0.460 \\
0.000 * * *\end{array}$ & & \\
\hline $\begin{array}{l}\text { FTSE } \\
\text { FLEDGLING }\end{array}$ & 2.8 & 2.0 & 627 & $\begin{array}{c}-1.960 \\
0.000 * * *\end{array}$ & $\begin{array}{c}-0.826 \\
0.000 * * *\end{array}$ & $\begin{array}{c}-0.350 \\
0.005^{* * *}\end{array}$ & \\
\hline $\begin{array}{l}\text { FTSE ALL } \\
\text { SHARES }\end{array}$ & 3.2 & 2.1 & 5824 & $\begin{array}{c}-1.553 \\
0.000 * * *\end{array}$ & $\begin{array}{c}-0.418 \\
0.000 * * *\end{array}$ & $\begin{array}{l}0.042 \\
0.957\end{array}$ & $\begin{array}{c}0.407 \\
0.000 * * *\end{array}$ \\
\hline $\begin{array}{l}\text { Source Between } \\
\text { Groups }\end{array}$ & $\begin{array}{c}\mathrm{df} \\
4\end{array}$ & $\begin{array}{c}\mathrm{F} \\
154.00\end{array}$ & $\begin{array}{l}\text { Prob }>\text { F } \\
0.000\end{array}$ & & & & \\
\hline \multicolumn{8}{|c|}{ Panel D: $t$-test for the difference between FTSE350 and FTSE SMALL and FLEDGLING } \\
\hline \multirow{2}{*}{ Diversity Indices } & \multicolumn{3}{|c|}{ FTSE 350} & \multicolumn{3}{|c|}{ FTSE SMALL and FLEDGLING } & \multirow{2}{*}{ T-Test Sig. } \\
\hline & $N$ & Mean & Median & $N$ & Mean & Median & \\
\hline $\begin{array}{l}\text { Statutory } \\
\text { Diversity }\end{array}$ & 3274 & 2.9 & 3.0 & 2885 & 2.4 & 2.0 & $* *$ \\
\hline $\begin{array}{l}\text { Competitive } \\
\text { Diversity }\end{array}$ & 3266 & 6.3 & 6.0 & 2882 & 6.0 & 6.0 & $* *$ \\
\hline $\begin{array}{l}\text { Demographic } \\
\text { Diversity }\end{array}$ & 3274 & 4.0 & 4.0 & 2883 & 3.1 & 3.0 & $* *$ \\
\hline
\end{tabular}

Level of significance for mean differences are ${ }^{* * *}: 0.01,{ }^{* *}: 0.05$.

In summary, the variation of board diversity clearly influences the performance of FTSE UK Indices, which proves our Hypothesis 1. This finding explains the performance of UK FTSE indices effects resulting from the variations in board diversity context due to variations in firm size, media exposure, legitimacy-seeking behaviour, and board openness. These findings add to the corporate governance literature by demonstrating that the characteristics of board of directors influence the stability of financial indices, which is of significant importance in understanding stock pricing and firm performance effects.

\subsection{Board Competitive Capital}

Table 6 reports the descriptive statistics of our sample of boards' competitive capital across the various UK FTSE indices. Panel (A) of Table 6 shows the association between the governance experience and performance of FTSE indices. As can be seen from the table, the most experienced directors in the UK were in the FTSE100 firms. It is worth noting that the smaller companies often had a less experienced board of directors, and thus the size of the firm is a significant factor here. Panel (B) of Table 6 reports the level of education on boards across the UK FTSE indices. Similar to governance experience, the FTSE100 firm boards featured higher levels of educational qualifications (FTSE100EQ = 2) compared to other UK FTSE index firms (FTSE Fledgling EQ = 1.3). This implies that larger companies have more 'qualified' directors to lead large scale operation than Small to Medium Enterprise (SMEs). Finally, panel (C) of Table 6 investigates the social network across UK FTSE indices. The findings indicate that the FTSE100 firms were significantly more connected, and their directors had larger networks. This is in line with Renneboog and Zhao [78], who found that UK directors of large firms are better connected. 
Table 6. Boards' competitive capital across the FTSE UK index series over 2000-2014.

\begin{tabular}{|c|c|c|c|c|c|c|c|}
\hline FTSE UK Index Series & Variables & $N$ & Mean & Median & Std. Dev. & $p 5$ & $p 95$ \\
\hline \multicolumn{8}{|c|}{ Panel A: Governance Experience on Quoted firms } \\
\hline \multirow{2}{*}{ FTSE100 } & Total board Governance Experience & \multirow{2}{*}{1089} & 43.71 & 42.00 & 17.20 & 20.00 & 74.00 \\
\hline & Average board Governance Experience (per director) & & 3.97 & 3.87 & 1.12 & 2.30 & 6.08 \\
\hline \multirow{2}{*}{ FTSE250 } & Total board Governance Experience & \multirow{2}{*}{2185} & 28.18 & 27.00 & 12.04 & 12.00 & 49.00 \\
\hline & Average board Governance Experience (per director) & & 3.49 & 3.33 & 1.30 & 1.63 & 5.80 \\
\hline \multirow{2}{*}{ FTSE SMALL CAP } & Total board Governance Experience & \multirow{2}{*}{2256} & 21.83 & 21.00 & 9.68 & 7.00 & 38.00 \\
\hline & Average board Governance Experience (per director) & & 3.44 & 3.14 & 1.52 & 1.30 & 6.25 \\
\hline \multirow{2}{*}{ FTSE FLEDGLING } & Total board Governance Experience & \multirow{2}{*}{629} & 18.38 & 16.00 & 11.52 & 5.00 & 38.00 \\
\hline & Average board Governance Experience (per director) & & 3.49 & 2.75 & 2.51 & 1.00 & 8.67 \\
\hline \multirow{2}{*}{ FTSE ALL SHARES } & Total board Governance Experience & \multirow{2}{*}{5834} & 14.94 & 13.00 & 8.91 & 5.00 & 32.00 \\
\hline & Average board Governance Experience (per director) & & 2.85 & 2.40 & 1.79 & 1.00 & 6.00 \\
\hline \multicolumn{8}{|c|}{ Panel B: Educational Qualifications (Academic and Professional) } \\
\hline \multirow{2}{*}{ FTSE100 } & Total board's number of Educ.qualifications & \multirow{2}{*}{1089} & 22.98 & 22.00 & 8.89 & 10.00 & 41.00 \\
\hline & Average board's educ. qualifications (per director) & & 2.07 & 2.09 & 0.50 & 1.20 & 2.87 \\
\hline \multirow{2}{*}{ FTSE250 } & Total board's number of Educ.qualifications & \multirow{2}{*}{2185} & 13.92 & 13.00 & 5.97 & 5.00 & 24.00 \\
\hline & Average board's educ. qualifications (per director) & & 1.69 & 1.67 & 0.56 & 0.83 & 2.64 \\
\hline \multirow{2}{*}{ FTSE SMALL CAP } & Total board's number of Educ.qualifications & \multirow[b]{2}{*}{2256} & 9.80 & 9.00 & 4.50 & 3.00 & 18.00 \\
\hline & Average board's educ. qualifications (per director) & & 1.50 & 1.44 & 0.56 & 0.60 & 2.50 \\
\hline \multirow{2}{*}{ FTSE FLEDGLING } & Total board's number of Educ.qualifications & \multirow{2}{*}{629} & 8.11 & 7.00 & 5.54 & 1.00 & 18.00 \\
\hline & Average board's educ. qualifications (per director) & & 1.34 & 1.33 & 0.69 & 0.33 & 2.57 \\
\hline \multirow{2}{*}{ FTSE ALL SHARES } & Total board's number of Educ.qualifications & \multirow{2}{*}{5834} & 7.65 & 7.00 & 4.28 & 2.00 & 16.00 \\
\hline & Average board's educ. qualifications (per director) & & 1.40 & 1.33 & 0.65 & 0.50 & 2.50 \\
\hline \multicolumn{8}{|c|}{ Panel C: Social Network } \\
\hline \multirow{2}{*}{ FTSE100 } & Total board social network & \multirow{2}{*}{1089} & 10.69 & 9.63 & 6.36 & 2.50 & 22.37 \\
\hline & Average board social network (per director) & & 0.94 & 0.91 & 0.42 & 0.29 & 1.63 \\
\hline \multirow{2}{*}{ FTSE250 } & Total board social network & \multirow{2}{*}{2185} & 4.68 & 4.20 & 2.92 & 0.91 & 10.08 \\
\hline & Average board social network (per director) & & 0.56 & 0.51 & 0.33 & 0.14 & 1.17 \\
\hline \multirow{2}{*}{ FTSE SMALL CAP } & Total board social network & 2256 & 3.07 & 2.55 & 2.19 & 0.52 & 7.41 \\
\hline & Average board social network (per director) & 2256 & 0.46 & 0.41 & 0.31 & 0.09 & 1.07 \\
\hline & Total board social network & & 2.36 & 1.88 & 2.11 & 0.14 & 6.54 \\
\hline FTSE FLEDGLING & Average board social network (per director) & 629 & 0.40 & 0.36 & 0.32 & 0.03 & 1.02 \\
\hline ETCF $\triangle \mathrm{UI}$ CHAPES & Total board social network & & 1.94 & 1.47 & 1.65 & 0.14 & 5.09 \\
\hline FISE ALL SHARES & Average board social network (per director) & 5834 & 0.35 & 0.28 & 0.29 & 0.03 & 0.90 \\
\hline
\end{tabular}


Table 7 reports those results associated with the Scheffé multiple group comparisons. Overall, the findings show the statistical significance of the difference between key compositions of board of directors across the UK FTSE indices. Panel (A) demonstrates that the difference among combined groups for board governance cumulative experience was statistically significant at the $1 \%$ level of significance, implying that the top combined boards are more experienced. The same pattern holds with educational qualifications and network size, as can be seen from panels (B) and (C) of Table 7. Panel (D) shows findings associated with a combination of FTSE100 and FTSE250 (i.e., FTSE350) firms versus a combination of FTSE SMALL and Fledgling firms. The results show that all board-related competitive capital criteria of FTSE350 firms outperformed those associated with FTSE SMALL-Fledgling group firms.

Table 7. Comparisons of group means for boards' competitive capital by the FTSE UK index series.

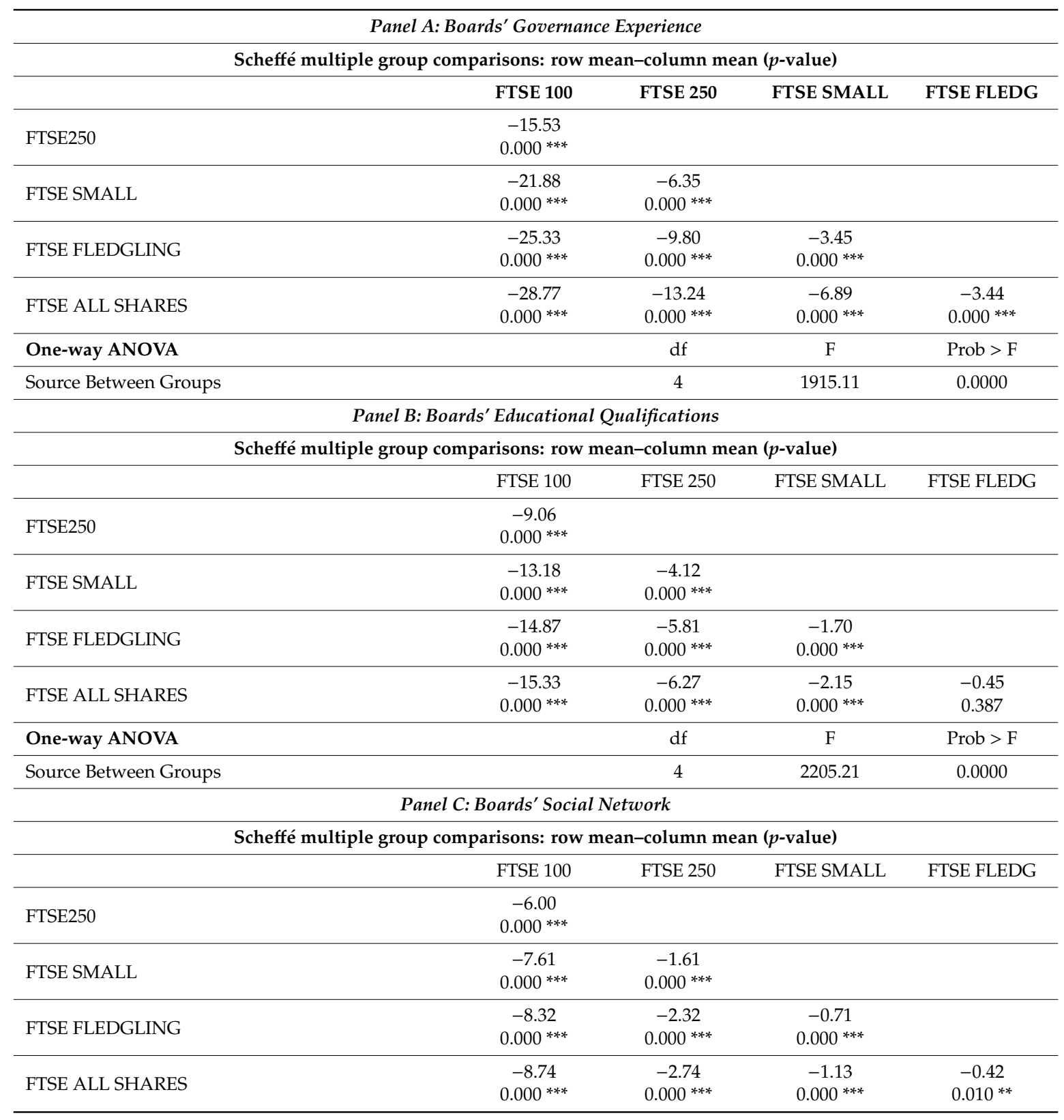


Table 7. Cont.

\begin{tabular}{|c|c|c|c|c|c|}
\hline One-way ANOVA & & & $\mathrm{df}$ & $\mathrm{F}$ & Prob $>$ F \\
\hline Source Between Groups & & & 4 & 2424.62 & 0.0000 \\
\hline \multicolumn{6}{|c|}{ Panel D: T-test for the difference between FTSE350 and FTSE SMALL and FLEDGLING } \\
\hline & \multicolumn{2}{|c|}{ FTSE 350} & \multicolumn{2}{|c|}{ FTSE SMALL and FLEDGLING } & \multirow{2}{*}{ T-Test Sig } \\
\hline & $N$ & Mean & $N$ & Mean & \\
\hline Boards' Governance Experience & 3274 & 33.34 & 2885 & 21.08 & $* * *$ \\
\hline Boards' Educational Qualifications & 3274 & 16.93 & 2885 & 9.43 & $* * *$ \\
\hline Boards' Social Network & 3274 & 6.68 & 2885 & 2.92 & $* * *$ \\
\hline
\end{tabular}

In summary, both approaches yielded a significant relationship between the performance of UK FTSE indices and the level of competitive capital, which proves our Hypothesis 2. This reflects the association between firm size and complexity, as well as the boards' requirement of competitive capital.

\subsection{Board Busyness}

Table 8 presents the distribution of SD and board busyness by type of UK FTSE index. In agreement with Ferris et al. [58], who found multiple directorships are more frequent in large firms, our analysis suggested that the percentage of busy boards increases parallel to firm size. Specifically, FTSE100 had the highest average number of board seats per non-executive director (NED) (2.5). Furthermore, as seen in Table 9 the FTSE100 exhibited the highest level of board busyness (39\%) compared to FTSE250 (board busyness $=33 \%$ ) and FTSE Fledgling (board busyness $=20 \%$ ). This could be explained by (i) the variations in the "selection effects" of holding multiple board seats (Adams et al., 2010). For example, reputable or qualified NEDs are more likely to hold more board seats; (ii) the FTSE100 is featured by good lead to busy directors. When grouping the FTSE indices into group A-FTSE350 (FTSE100 and FTSE250) and Group B, we found that group A-FTSE350 firms had a lower level of board busyness compared to group B, implying a great deal of regulators' restrictions imposed on the number of seats held by group A (FTSE3350).

In summary, the level of board busyness clearly and significantly varies and influences the performance of UK FTSE indices, which proves our Hypothesis 3. 
Table 8. Boards' busyness across the FTSE UK index series over 2000-2014

\begin{tabular}{|c|c|c|c|c|c|c|c|}
\hline & Variables & $N$ & Mean & Median & Std.Dev. & $p 5$ & p95 \\
\hline \multirow{3}{*}{$\begin{array}{c}\text { FTSE } \\
100\end{array}$} & Average number of board seats per NED on Firm Board & 800 & 2.51 & 2.43 & 0.63 & 1.67 & 3.70 \\
\hline & Board Busyness 3 (based on the percentage of busy directors) & 1089 & $12.40 \%$ & $0.00 \%$ & $32.97 \%$ & $0.00 \%$ & $100.00 \%$ \\
\hline & Board Busyness 4 (based on the percentage of busy NEDs) & 1089 & $38.93 \%$ & $0.00 \%$ & $48.78 \%$ & $0.00 \%$ & $100.00 \%$ \\
\hline \multirow{3}{*}{$\begin{array}{c}\text { FTSE } \\
250\end{array}$} & Average number of board seats per NED on Firm Board & 1768 & 2.40 & 2.25 & 0.81 & 1.33 & 4.00 \\
\hline & Board Busyness 3 (based on the percentage of busy directors) & 2185 & $11.17 \%$ & $0.00 \%$ & $31.50 \%$ & $0.00 \%$ & $100.00 \%$ \\
\hline & Board Busyness 4 (based on the percentage of busy NEDs) & 2185 & $33.18 \%$ & $0.00 \%$ & $47.10 \%$ & $0.00 \%$ & $100.00 \%$ \\
\hline \multirow{3}{*}{$\begin{array}{c}\text { FTSE } \\
\text { SMALL }\end{array}$} & Average number of board seats per NED on Firm Board & 1759 & 2.38 & 2.25 & 0.79 & 1.25 & 3.80 \\
\hline & Board Busyness 3 (based on the percentage of busy directors) & 2256 & $16.36 \%$ & $0.00 \%$ & $37.00 \%$ & $0.00 \%$ & $100.00 \%$ \\
\hline & Board Busyness 4 (based on the percentage of busy NEDs) & 2243 & $32.14 \%$ & $0.00 \%$ & $46.71 \%$ & $0.00 \%$ & $100.00 \%$ \\
\hline \multirow{3}{*}{$\begin{array}{c}\text { FTSE } \\
\text { FLEDGLING }\end{array}$} & Average number of board seats per NED on Firm Board & 437 & 2.34 & 2.00 & 1.37 & 1.00 & 5.25 \\
\hline & Board Busyness 3 (based on the percentage of busy directors) & 629 & $14.15 \%$ & $0.00 \%$ & $34.88 \%$ & $0.00 \%$ & $100.00 \%$ \\
\hline & Board Busyness 4 (based on the percentage of busy NEDs) & 620 & $20.00 \%$ & $0.00 \%$ & $40.03 \%$ & $0.00 \%$ & $100.00 \%$ \\
\hline \multirow{3}{*}{$\begin{array}{c}\text { FTSE } \\
\text { ALL SHARE }\end{array}$} & Average number of board seats per NED on Firm Board & 4017 & 2.07 & 1.88 & 1.07 & 1.00 & 4.00 \\
\hline & Board Busyness 3 (based on the percentage of busy directors) & 5834 & $6.77 \%$ & $0.00 \%$ & $25.13 \%$ & $0.00 \%$ & $100.00 \%$ \\
\hline & Board Busyness 4 (based on the percentage of busy NEDs) & 5759 & $25.13 \%$ & $0.00 \%$ & $43.38 \%$ & $0.00 \%$ & $100.00 \%$ \\
\hline
\end{tabular}


Table 9. Comparisons of group means for boards' busyness by the FTSE UK index series.

\begin{tabular}{|c|c|c|c|c|c|}
\hline \multicolumn{6}{|c|}{ Panel A: Average number of board seats per NED on Firm Board } \\
\hline \multicolumn{6}{|c|}{ Scheffé multiple group comparisons: row mean - column mean ( $p$-value) } \\
\hline & & FTSE 100 & FTSE 250 & $\begin{array}{l}\text { FTSE } \\
\text { SMALL }\end{array}$ & $\begin{array}{l}\text { FTSE } \\
\text { FLEDG }\end{array}$ \\
\hline FTSE250 & & $\begin{array}{l}-0.11 \\
0.099\end{array}$ & & & \\
\hline FTSE SMALL & & $\begin{array}{c}-0.13 \\
0.029^{* *}\end{array}$ & $\begin{array}{l}-0.02 \\
0.983\end{array}$ & & \\
\hline FTSE FLEDGLING & & $\begin{array}{l}-0.17 \\
0.062 *\end{array}$ & $\begin{array}{l}-0.06 \\
0.875\end{array}$ & $\begin{array}{l}-0.04 \\
0.973\end{array}$ & \\
\hline FTSE ALL SHARES & & $\begin{array}{l}-0.44 \\
0.000 * * *\end{array}$ & $\begin{array}{c}-0.33 \\
0.000 * * * \\
\end{array}$ & $\begin{array}{c}-0.31 \\
0.000 * * * \\
\end{array}$ & $\begin{array}{c}-0.27 \\
0.000 * * * \\
\end{array}$ \\
\hline One-way ANOVA & & & $\mathrm{df}$ & $\mathrm{F}$ & Prob $>$ F \\
\hline Source Between Groups & & & 4 & 71.23 & $0.000 * * *$ \\
\hline \multicolumn{6}{|c|}{ Panel B: Board Busyness 3 (based on the percentage of busy directors) } \\
\hline \multicolumn{6}{|c|}{ Scheffé multiple group comparisons: row mean-column mean ( $p$-value) } \\
\hline & & FTSE 100 & FTSE 250 & $\begin{array}{c}\text { FTSE } \\
\text { SMALL }\end{array}$ & $\begin{array}{l}\text { FTSE } \\
\text { FLEDG }\end{array}$ \\
\hline FTSE250 & & $\begin{array}{l}-0.01 \\
0.876\end{array}$ & & & \\
\hline FTSE SMALL & & $\begin{array}{c}0.04 \\
0.013^{* *}\end{array}$ & $\begin{array}{c}0.05 \\
0.000^{* * *}\end{array}$ & & \\
\hline FTSE FLEDGLING & & $\begin{array}{c}0.02 \\
0.853\end{array}$ & $\begin{array}{l}0.03 \\
0.31\end{array}$ & $\begin{array}{c}-0.02 \\
0.62 \\
\end{array}$ & \\
\hline FTSE ALL SHARES & & $\begin{array}{c}-0.06 \\
0.000 * * *\end{array}$ & $\begin{array}{c}-0.04 \\
0.000 * * *\end{array}$ & $\begin{array}{l}-0.10 \\
0.000 * * *\end{array}$ & $\begin{array}{c}-0.07 \\
0.000 * * *\end{array}$ \\
\hline One-way ANOVA & & & $\mathrm{df}$ & F & Prob $>F$ \\
\hline Source Between Groups & & & 4 & 47.13 & $0.000 * * *$ \\
\hline \multicolumn{6}{|c|}{ Panel C: Board Busyness 4 (based on the percentage of busy NEDs) } \\
\hline \multicolumn{6}{|c|}{ Scheffé multiple group comparisons: row mean-column mean ( $p$-value) } \\
\hline & & FTSE 100 & FTSE 250 & $\begin{array}{l}\text { FTSE } \\
\text { SMALL }\end{array}$ & $\begin{array}{l}\text { FTSE } \\
\text { FLEDG }\end{array}$ \\
\hline FTSE250 & & $\begin{array}{c}-0.06 \\
0.019^{* *}\end{array}$ & & & \\
\hline FTSE SMALL & & $\begin{array}{c}-0.07 \\
0.002 * * *\end{array}$ & $\begin{array}{l}-0.01 \\
0.965\end{array}$ & & \\
\hline FTSE FLEDGLING & & $\begin{array}{c}-0.19 \\
0.000^{* * *}\end{array}$ & $\begin{array}{c}-0.13 \\
0.000 * * * \\
\end{array}$ & $\begin{array}{c}-0.12 \\
0.000 * * *\end{array}$ & \\
\hline FTSE ALL SHARES & & $\begin{array}{l}-0.14 \\
0.000 * * *\end{array}$ & $\begin{array}{c}-0.08 \\
0.000 * * *\end{array}$ & $\begin{array}{c}-0.07 \\
0.000 * * *\end{array}$ & $\begin{array}{l}0.051 \\
0.124\end{array}$ \\
\hline One-way ANOVA & & & $\mathrm{df}$ & $\mathrm{F}$ & Prob $>F$ \\
\hline Source Between Groups & & & 4 & 37.47 & $0.000 * * *$ \\
\hline \multicolumn{6}{|c|}{ Panel D: T-test for the difference between FTSE350 and FTSE SMALL and FLEDGLING } \\
\hline & \multicolumn{2}{|c|}{ FTSE 350} & \multicolumn{2}{|c|}{$\begin{array}{l}\text { FTSE SMALL and } \\
\text { FLEDGLING }\end{array}$} & T-Test Sig. \\
\hline & $\mathrm{N}$ & Mean & $\mathrm{N}$ & Mean & \\
\hline $\begin{array}{l}\text { Average number of board seats per } \\
\text { NED on Firm Board }\end{array}$ & 2568 & 2.43 & 2196 & 2.37 & $* * *$ \\
\hline $\begin{array}{l}\text { Board Busyness } 3 \text { (based on the } \\
\text { percentage of busy directors) }\end{array}$ & 3274 & 0.1158 & 2885 & 0.1588 & $* * *$ \\
\hline $\begin{array}{l}\text { Board Busyness } 4 \text { (based on the } \\
\text { percentage of busy NEDs) }\end{array}$ & 3274 & 0.3509 & 2863 & 0.2951 & $* * *$ \\
\hline
\end{tabular}




\section{Conclusions}

This paper examined the impact of board characteristics on firm performance across various FTSE UK Index Series indices. We tested the impact of key three determinants of board characteristics and their impact on firm performance across different FTSE indices, namely: board diversity (including statutory, competitive, and demographic diversity), board competitive capital, and board busyness of the board of the UK public listed firms. To test our hypotheses and consider differences amongst the UK FTSE indices, a one-way analysis of variance (i.e., one-way ANOVA) was used. One-way ANOVA is common in assessing the likelihood of three or more distinct groups being different as the result of chance alone. We further complemented this by using a number of post-hoc multiple comparison methods (e.g., the Least Significant Difference (LSD) t-test and Scheffé's test) to enable multiple comparisons of group means.

We found that different dimensions of board characteristics are significantly correlated with the performance of FTSE UK indices. Boards with higher scores on diversity maintain greater levels of governance effectiveness in FTSE100 and FTSE250 firms. Interestingly, we found that board competitive capital and busyness associated with FTSE100 firms have the most experienced, highest educated, and most socially connected boards, with a general trend of boards becoming significantly less 'competitive' as firm size decreases. The boards of FTSE100 and FTSE250 firms are the most diverse, while the boards of low-capitalised firms, FTSE SMALLCAP and FTSE Fledgling firms, are associated with a lower level of board diversity. Regarding a board's competitive capital, FTSE100 firms were found to have the most experienced, highest educated, and most socially connected boards, and there was with a general trend of boards becoming significantly less 'competitive' as firm size decreased. Finally, in compliance with different governance codes and reports, we found that although NEDs sitting on FTSE350 boards are busier than their counterparts on other indices, overall the boards of FTSE350 firms are less busy than those of the firms of other indices. There are a number of implications for research and practice from this study. Firstly, the study offers insights and provides important solutions to empower and enhance approaches to composition of company boards according to organisational and financial characteristics and to reach an 'optimal level' of diversity. Secondly, our findings offer insights to those policy-makers who regularly adopt governance regulations to minimise possible future conflicts of interest. Our analysis in this study highlights the significance of board competitive capital and busyness to minimise possible future conflicts of interest. It also highlights the significance of various diversity indices and boards' competitive capital. On the basis of this analysis and these results, we outlined some strategic implications in forming better policies and strategies for financial markets and institutions, as well as for financial consultants.

The major limitation of this paper is that the stock market index level analysis was dependent on the integrity of the proxy for the management board diversity, which was obtained from perception-based measures. Hence, omitted variables associated with the diversification dimension of indicators may significantly impact perceptions of the quality of board characteristics and subsequently reflect negatively on the value of the substantive link between the board diversity strategies and listed companies on the stock exchange. Another limitation is that agency theory assumes that the degree of agency conflict and costs is a function of managerial ownership, which has not been explored in the cross-index analysis. Our study highlights a number of avenues for future research. For example, different board competitive capital indicators, such as sector knowledge, board educational backgrounds, and professional qualifications, could be used to further investigate the relationship between management board characteristics and listing companies on a stock exchange. Furthermore, similar investigation and comparisons could be researched by conducting more precise governance/management board factors and potential micro effects of ownership structure on board performance, which are undoubtedly a promising area for future investigations. 
Author Contributions: “Conceptualization, A.Y.; methodology, A.Y. formal analysis, A.Y.; data curation, A.Y.; writing-review and editing, M.S.; All authors have read and agreed to the published version of the manuscript.", please turn to the CRediT taxonomy for the term explanation. Authorship must be limited to those who have contributed substantially to the work reported.

Funding: This research received no external funding.

Conflicts of Interest: The authors declare no conflict of interest.

\section{References}

1. Aggarwal, R.; Schloetzer, J.D.; Williamson, R. Do Corporate Governance Mandates Impact Long-Term Firm Value and Governance Culture? J. Corp. Financ. 2019, 59, 202-217. [CrossRef]

2. Brennan, N.M.; Subramaniam, N.; van Staden, C.J. Corporate Governance Implications of Disruptive Technology: An Overview. Br. Account. Rev. 2019, 51. [CrossRef]

3. Adsera, A.; Boix, C.; Payne, M. Are You Being Served? Political Accountability and Quality of Government. J. Law Econ. Organ. 2003, 19, 445-490. [CrossRef]

4. Thomas, M.A. What Do the Worldwide Governance Indicators Measure? Eur. J. Dev. Res. 2010, $22,31-54$. [CrossRef]

5. Zurawicki, L.; Habib, M. Corruption and Foreign Direct Investment: What Have We Learned? Int. Bus. Econ. Res. J. 2010, 9. [CrossRef]

6. Ben-Amar, W.; Francoeur, C.; Hafsi, T.; Labelle, R. What Makes Better Boards? A Closer Look at Diversity and Ownership. Br. J. Manag. 2013, 24, 85-101. [CrossRef]

7. Hooper, V.; Sim, A.B.; Uppal, A. Governance and Stock Market Performance. Econ. Syst. 2009, 33, 93-116. [CrossRef]

8. Adams, R.B.; Hermalin, B.E.; Weisbach, M.S. The Role of Boards of Directors in Corporate Governance: A Conceptual Framework and Survey. J. Econ. Lit. 2010, 48, 58-107. [CrossRef]

9. Fauver, L.; Hung, M.; Li, X.; Taboada, A.G. Board Reforms and Firm Value: Worldwide Evidence. J. Financ. Econ. 2017, 125, 120-142. [CrossRef]

10. Rosenstein, S.; Wyatt, J.G. Outside Directors, Board Independence, and Shareholder Wealth. J. Financ. Econ. 1990, 26, 175-191. [CrossRef]

11. Sherif, M.; Chen, J. The Quality of Governance and Momentum Profits: International Evidence. Br. Account. Rev. 2019, 51, 100835. [CrossRef]

12. Hu, J.; Li, S.; Taboada, A.G.; Zhang, F. Corporate Board Reforms around the World and Stock Price Crash Risk. J. Corp. Financ. 2020, 62, 101557. [CrossRef]

13. Chen, R.; Dyball, M.C.; Wright, S. The Link between Board Composition and Corporate Diversification in Australian Corporations. Corp. Gov. Int. Rev. 2009, 17, 208-223. [CrossRef]

14. Crespí-Cladera, R.; Pascual-Fuster, B. Does the Independence of Independent Directors Matter? J. Corp. Financ. 2014, 28, 116-134. [CrossRef]

15. Duchin, R.; Matsusaka, J.G.; Ozbas, O. When Are Outside Directors Effective? J. Financ. Econ. 2010, 96, 195-214. [CrossRef]

16. Kang, H.; Cheng, M.; Gray, S.J. Corporate Governance and Board Composition: Diversity and Independence of Australian Boards. Corp. Gov. Int. Rev. 2007, 15, 194-207. [CrossRef]

17. Minton, B.A.; Taillard, J.; Williamson, R.G. Do Independence and Financial Expertise of the Board Matter for Risk Taking and Performance? Available at SSRN 2011, 1-66. Available online: https://papers.ssrn.com/sol3/ papers.cfm?abstract_id=1661855 (accessed on 30 June 2020). [CrossRef]

18. Huse, M. Accountability and Creating Accountability: A Framework for Exploring Behavioural Perspectives of Corporate Governance. Br. J. Manag. 2005, 16, S65-S79. [CrossRef]

19. Bhagat, S.; Black, B. The Non-Correlation Between Board Independence and Long Term Firm Performance. J. Corp. Law 2001, 1, 231-274. [CrossRef]

20. Dalton, D.R.; Daily, C.M.; Certo, S.T.; Roengpitya, R. Meta-Analyses of Financial Performance and Equity: Fusion or Confusion? Acad. Manag. J. 2003, 46, 13-26. [CrossRef]

21. Kiel, G.C.; Nicholson, G.J. Board Composition and Corporate Performance: How the Australian Experience Informs Contrasting Theories of Corporate Governance. Corp. Gov. Int. Rev. 2003, 11, 189-205. [CrossRef] 
22. Hillman, A.J.; Dalziel, T. Boards of Directors and Firm-Performance: Integrating Agency and Resource Dependence Perspectives. Acad. Manag. Rev. 2003, 28, 383-396. [CrossRef]

23. Kiel, G.C.; Nicholson, G.J. Multiple Directorships and Corporate Performance in Australian Listed Companies. Corp. Gov. Int. Rev. 2006, 14, 530-546. [CrossRef]

24. Barney, J. Firm Resources and Sustained Competitive Advantage. J. Manag. 1991, 17, 99-120. [CrossRef]

25. Pfeffer, J.; Salancik, G. The External Control of Organizations: A Resource Dependence Perspective; Harper and Row: Manhattan, NY, USA, 1978.

26. Daily, C.M.; Dalton, D.R.; Cannella, A.A. Corporate Governance: Decades of Dialogue and Data. Acad. Manag. Rev. 2003, 28, 371-382. [CrossRef]

27. Cohen, S.G.; Bailey, D.E. What Makes Teams Work: Group Effectiveness Research from the Shop Floor to the Executive Suite. J. Manag. 1997, 23, 239-290. [CrossRef]

28. Forbes, D.P.; Milliken, F.J. Cognition and Corporate Governance: Understanding Boards of Directors as Strategic Decision-Making Groups. Acad. Manag. Rev. 1999, 24, 489-505. [CrossRef]

29. Anderson, R.C.; Reeb, D.M.; Upadhyay, A.; Zhao, W. The Economics of Director Heterogeneity. Financ. Manag. 2011, 40, 5-38. [CrossRef]

30. De Andres, P.; Azofra, V.; Lopez, F. Corporate Boards in OECD Countries: Size, Composition, Functioning and Effectiveness. Corp. Gov. Int. Rev. 2005, 13, 197-210. [CrossRef]

31. Molz, R. The Theory of Pluralism in Corporate Governance: A Conceptual Framework and Empirical Test. J. Bus. Ethics 1995, 14, 789-804. [CrossRef]

32. Musteen, M.; Datta, D.K.; Kemmerer, B. Corporate Reputation: Do Board Characteristics Matter? Br. J. Manag. 2010, 21, 498-510. [CrossRef]

33. Tuggle, C.S.; Schnatterly, K.; Johnson, R.A. Attention Patterns in the Boardroom: How Board Composition and Processes Affect Discussion of Entrepreneurial Issues. Acad. Manag. J. 2010, 53, 550-571. [CrossRef]

34. Fama, E.F.; Jensen, M.C. Separation of Ownership and Control. J. Law Econ. 1983, 26, 301-325. [CrossRef]

35. Dalton, D.R.; Daily, C.M.; Ellstrand, A.E.; Johnson, J.L. Meta-Analytic Review of Board Composition, Leadership Structure, and Financial Performance. Strateg. Manag. J. 1998, 19, 269-290. [CrossRef]

36. Hermalin, B.E.; Weisbach, M.S. Boards Of Directors as an Endogenously Determined Institution: A Survey of the Economic Literature. Econ. Policy Rev. 2003, 9, 7-26. [CrossRef]

37. Huse, M.; Hoskisson, R.; Zattoni, A.; Viganò, R. New Perspectives on Board Research: Changing the Research Agenda. J. Manag. Gov. 2009, 15, 5-28. [CrossRef]

38. Siebels, J.-F.; Knyphausen-Aufseß, D. A Review of Theory in Family Business Research: The Implications for Corporate Governance. Int. J. Manag. Rev. 2012, 14, 280-304. [CrossRef]

39. Milliken, F.J.; Martins, L.L. Searching for Common Threads: Understanding the Multiple Effects of Diversity in Organizational Groups. Acad. Manag. Rev. 1996, 21, 402-433. [CrossRef]

40. Li, F. Endogeneity in CEO Power: A Survey and Experiment. Invest. Anal. J. 2016, 45, 149-162. [CrossRef]

41. Coles, J.L.; Li, Z.F. An Empirical Assessment of Empirical Corporate Finance. Available at SSRN 2019, 1-109. Available online: https://papers.ssrn.com/sol3/papers.cfm?abstract_id=1997535 (accessed on 30 June 2020). [CrossRef]

42. Agrawal, A.; Knoeber, C.R. Do Some Outside Directors Play a Political Role? J. Law Econ. 2001, 44, $179-198$. [CrossRef]

43. Financial Reporting Council. The Combined Code on Corporate Governance; FRC: London, UK, 2003. [CrossRef]

44. Financial Reporting Council. The Combined Code on Corporate Governance; FRC: London, UK, 2008.

45. Walker, D. A Review of Corporate Governance in UK Banks and other Financial Industry Entities: Final Recommendations; HM Treasury: London, UK, 2009. Available online: http://www.hmtreasury.gov.uk/ walkereview_information.htm (accessed on 28 September 2009).

46. Davies, M. The Women on Boards; UK Department for Business, Innovation \& Skills: London, UK, 2011.

47. Mulcahy, M.; Linehan, C. Females and Precarious Board Positions: Further Evidence of the Glass Cliff. Br. J. Manag. 2014, 25, 425-438. [CrossRef]

48. Hambrick, D.C.; Mason, P.A. Upper Echelons: The Organization as a Reflection of Its Top Managers. Acad. Manag. Rev. 1984, 9, 193-206. [CrossRef]

49. Wiersema, M.F.; Bantel, K.A. Top Management Team Demography and Corporate Strategic Change. Acad. Manag. J. 1992, 35, 91-121. 
50. Giannetti, M.; Liao, G.; Yu, X. The Brain Gain of Corporate Boards: A Natural Experiment from China. J. Financ. 2015, 70, 1629-1682. [CrossRef]

51. Chen, H.L. Board Capital, CEO Power and R\&D Investment in Electronics Firms. Corp. Gov. Int. Rev. 2014, 22, 422-436. [CrossRef]

52. Dalziel, T.; Gentry, R.J.; Bowerman, M. An Integrated Agency-Resource Dependence View of the Influence of Directors' Human and Relational Capital on Firms' R\&D Spending. J. Manag. Stud. 2011, 48, 1217-1242. [CrossRef]

53. Tian, J.J.; Haleblian, J.J.; Rajagopalan, N. The Effects of Board Human and Social Capital on Investor Reactions to New CEO Selection. Strateg. Manag. J. 2011, 32, 731-747. [CrossRef]

54. Gore, A.K.; Matsunaga, S.; Eric Yeung, P. The Role of Technical Expertise in Firm Governance Structure: Evidence from Chief Financial Officer Contractual Incentives. Strateg. Manag. J. 2011, 32, 771-786. [CrossRef]

55. Haynes, K.; Hillman, A. The Effect of Board Capital and CEO Power on Strategic Change. Strateg. Manag. J. 2010, 31, 1145-1163. [CrossRef]

56. Rhee, M.; Lee, J.H. The Signals Outside Directors Send to Foreign Investors: Evidence from Korea. Corp. Gov. Int. Rev. 2008, 16, 41-51. [CrossRef]

57. McDonald, M.L.; Westphal, J.D.; Graebner, M.E. What Do They Know? The Effects of Outside Director Acquisition Experience on Firm Acquisition Performance. Strateg. Manag. J. 2008, 29, 1155-1177. [CrossRef]

58. Ferris, S.P.; Jagannathan, M.; Pritchard, A.C. Too Busy to Mind the Business? Monitoring by Directors with Multiple Board Appointments. J. Financ. 2003, 58, 1087-1112. [CrossRef]

59. Fich, E.M.; Shivdasani, A. Are Busy Boards Effective Monitors? J. Financ. 2006, 61, 689-724. [CrossRef]

60. Hallock, K.F. Reciprocally Interlocking Board of Directors and Executive Compensation. J. Financ. Quant. Anal. 1997, 32, 331-344. [CrossRef]

61. Kaczmarek, S.; Kimino, S.; Pye, A. Interlocking Directorships and Firm Performance in Highly Regulated Sectors: The Moderating Impact of Board Diversity. J. Manag. Gov. 2014, 18, 347-372. [CrossRef]

62. Mazzola, E.; Perrone, G.; Kamuriwo, D.S. The Interaction between Inter-Firm and Interlocking Directorate Networks on Firm's New Product Development Outcomes. J. Bus. Res. 2014, 69, 672-682. [CrossRef]

63. Ong, C.-H.; Wan, D.; Ong, K.-S. An Exploratory Study on Interlocking Directorates in Listed Firms in Singapore. Corp. Gov. Int. Rev. 2003, 11, 322-334. [CrossRef]

64. Perry, T.; Peyer, U. Board Seat Accumulation by Executives: A Shareholder's Perspective. J. Financ. 2005, 60, 2083-2123. [CrossRef]

65. Pombo, C.; Gutiérrez, L.H. Outside Directors, Board Interlocks and Firm Performance: Empirical Evidence from Colombian Business Groups. J. Econ. Bus. 2011, 63, 251-277. [CrossRef]

66. Devos, E.; Prevost, A.; Puthenpurackal, J. Are Interlocked Directors Effective Monitors? Financ. Manag. 2009, 38, 861-887. [CrossRef]

67. Falato, A.; Kadyrzhanova, D.; Lel, U. Distracted Directors: Does Board Busyness Hurt Shareholder Value? J. Financ. Econ. 2014, 113, 404-426. [CrossRef]

68. Davis, J.H.; Schoorman, F.D.; Donaldson, L. Toward a Stewardship Theory of Management. Acad. Manag. Rev. 1997, 22, 20-47. [CrossRef]

69. Johansen, T.R.; Pettersson, K. The Impact of Board Interlocks on Auditor Choice and Audit Fees. Corp. Gov. Int. Rev. 2013, 21, 287-310. [CrossRef]

70. Harris, I.G.; Shimizu, K. Too Busy to Serve? An Examination of the Influence of Overboarded Directors. J. Manag. Stud. 2004, 41, 775-798. [CrossRef]

71. O'Sullivan, N. Managers as Monitors: An Analysis of the Non-Executive Role of Senior Executives in UK Companies. Br. J. Manag. 2000, 11, 17-29. [CrossRef]

72. Financial Reporting Council. The UK Stewardship Code; FRC: London, UK, 2010.

73. Mura, R. Firm Performance: Do Non-Executive Directors Have Minds of Their Own? Evidence from UK Panel Data. Financ. Manag. 2007, 36, 81-112. [CrossRef]

74. Doucouliagos, H.; Haman, J.; Askary, S. Directors' Remuneration and Performance in Australian Banking. Corp. Gov. Int. Rev. 2007, 15, 1363-1383. [CrossRef]

75. Aebi, V.; Sabato, G.; Schmid, M. Risk Management, Corporate Governance, and Bank Performance in the Financial Crisis. J. Bank. Financ. 2012, 36, 3213-3226. [CrossRef]

76. Colpan, A.M.; Yoshikawa, T. Performance Sensitivity of Executive Pay: The Role of Foreign Investors and Affiliated Directors in Japan. Corp. Gov. Int. Rev. 2012, 20, 547-561. [CrossRef] 
77. Mallin, C.; Melis, A.; Gaia, S. The Remuneration of Independent Directors in the UK and Italy: An Empirical Analysis Based on Agency Theory. Int. Bus. Rev. 2015, 24, 175-186. [CrossRef]

78. Renneboog, L.; Zhao, Y. Us Knows Us in the UK: On Director Networks and CEO Compensation. J. Corp. Financ. 2011, 17, 1132-1157. [CrossRef]

(C) 2020 by the authors. Licensee MDPI, Basel, Switzerland. This article is an open access article distributed under the terms and conditions of the Creative Commons Attribution (CC BY) license (http://creativecommons.org/licenses/by/4.0/). 